\title{
Confronting Duch: civil party participation in Case 001 at the Extraordinary Chambers in the Courts of Cambodia
}

\section{Eric Stover, Mychelle Balthazard and K. Alexa Koenig*}

Eric Stover is Faculty Director of the Human Rights Center and Adjunct Professor of Law and Public Health, University of California, Berkeley. He was an Open Society Fellow in 2009-2010. Mychelle Balthazard is the Cambodia Coordinator for the Human Rights Center, University of California, Berkeley and a PhD Candidate in International Development at the Payson Center of Tulane University. K. Alexa Koenig is a Researcher at the Human Rights Center and a PhD Candidate in Jurisprudence and Social Policy at the University of California, Berkeley.

\section{Abstract}

The Extraordinary Chambers in the Courts of Cambodia (ECCC) is unique because it is the first international criminal tribunal to allow victims of alleged crimes to act as civil parties at trial. This means that victims can have a role at the ECCC beyond being called as witnesses. After presenting the history of victim participation in

* Research for this article was supported in part by a grant from the Open Society Fellowship of the Open Society Institute. The authors wish to thank Jonathan Cobb for his editorial assistance. We are also grateful to Ben Batros, Camille Crittenden, Tracey Gurd, Victor Peskin, and Heather Ryan for reviewing the article. 
national and international war crimes trials, this article examines how civil party participation shaped the trial proceedings at the ECCC, and how the civil parties viewed their interactions with the court. It concludes by reflecting on the positive and negative aspects of civil party participation in the Duch trial, and what implications such participation may have for future trials at the ECCC and other international criminal courts.

To keep you is no gain, to destroy you is no loss.

(Khmer Rouge slogan)

The older you become, the more the history of the genocide comes back to you in an insidious way, a bit like poison that has been distilled into your body bit by bit. The only way to relieve things is to testify.

(Rithy Panh, Cambodian film director and screenwriter)

On 18 August 2009, the trial of Kaing Guek Eav (alias 'Duch') was in full swing in the courtroom of the Extraordinary Chambers in the Courts of Cambodia (ECCC) when a 52-year-old farmer named Neth Phally asked the presiding judge if he could show the court a photograph of his brother who had died at ' $S-21$ ', the notorious Tuol Sleng detention centre. Between 1975 and 1979, the accused, a former maths teacher turned Khmer Rouge revolutionary, had overseen the torture and execution of more than 12,000 people in his capacity as the prison's head.

With the judge's approval, Neth Phally carefully took out an 8-by-11-inch photograph of a young man with black, short-cropped hair and held it upright on the witness table in front of him. 'I would like to show a photo of my brother', he said. ' $[\mathrm{I}] \mathrm{t}$ is like he is sitting here ... next to me ... I believe that my brother will be at peace, having learned that justice is achieved through this court'. Phally leaned forward and turned to speak directly to his brother's image: 'The soul of you [will] be here with me and in the photo forever so that I can pay homage to you and dedicate ... offerings ... to you. I [will] never find [your] dead body... [so] this photo... represents the ashes and body of you'. ${ }^{1}$

It was itself an extraordinary moment, rarely seen in the courtrooms of international criminal tribunals, where judges seldom, if ever, let victims or witnesses tell their stories for their own sake, and often admonish those who stray from reporting facts.

Three months after Neth Phally testified in Phnom Penh, we travelled to his farm in Kampong Cham province where he lives with his mother, his wife, and their

1 Extraordinary Chambers in the Courts of Cambodia (ECCC), Prosecutor v. Kaing Guek Eav alias 'Duch', Case No. 001/18-07-2077-ECCC/TC, available at: http//www.eccc.gov.kh/en/case/topic/l (last visited 1 September 2011). See also Neth Phally's testimony on ECCC, Transcript of Trial Proceedings - Kaing Guek Eav 'Duch', Case File No. 001/18-07-2007-ECCCC/TC, 18 August 2009, Trial Day 60, pp. 109-110, available at: http:/www.ecc.gov.kh/sites/default/files/documents/courtdoc/E1_64.1_ TR001_20090818_Final_EN_Pub.pdf (last visited 7 September 2011). 
teenage daughter. Phally took us to a small shrine he had recently built at the back of the house. Hanging above the altar, surrounded by incense sticks and a painting of the Buddha, was the portrait of his brother. 'What had led him to show the photograph in the courtroom?' we asked. 'There were many reasons', he replied.

To begin with, I wanted to show Duch my brother so he would know I was not accusing him for no reason. I also wanted my brother to see the man who was responsible for his suffering. You see when my brother was taken to Tuol Sleng he was blindfolded and couldn't see anyone. But in the courtroom I could show him the accused... I felt this would help release his soul from wandering and help him find peace so he could be reborn again. ${ }^{2}$

Neth Phally was one of ninety Cambodians and foreigners who participated in the Duch trial as 'civil parties' (in French, 'parties civiles'). Of these, twenty-two testified in court about their imprisonment at S-21 or about the loss of one or more of their relatives there. ${ }^{3}$ To be accepted by the court as a civil party, each of the ninety had to show evidence of a 'physical, material or psychological' injury as a 'direct consequence' of the offences alleged in Duch's indictment. ${ }^{4}$ Unlike regular witnesses, they testified without taking an oath, could participate at various stages of the trial proceedings, and could comment in court upon the awarding of any reparations. ${ }^{5}$

Established in 2006 after prolonged negotiations between the Cambodian government and the United Nations, the $\mathrm{ECCC}^{6}$ is a national court with the mandate to try senior leaders and those most responsible for genocide, crimes against humanity, serious war crimes, and other crimes under Cambodian law that

2 Interview with Neth Phally, Kampong Cham province, 13 November 2009.

3 There were ninety-four civil party applicants at the initial hearing of the Duch trial in February 2009. During the investigation phase, twenty-eight were accepted as civil parties. During the trial, four of the remaining sixty-six applicants were rejected or withdrew their application. The sixty-two that were left had a provisional civil party status throughout the trial. Twenty-four of the sixty-two were ultimately denied civil party status at the judgment. Out of the pool of accepted and provisional civil parties, twenty-two were selected by the judges to testify at trial from a list submitted by the civil party lawyers. Decisions on civil parties' acceptance are detailed in Case 001, ECCC Trial Chamber, Judgment: see ECCC, Case File No. 001/18-7-2007/ECCC/TC, paras. 637-638, Judgment (Trial Chamber), 26 July 2010, available at: http//www.ecc.gov.kh/en/documents/court/judgement-case-001 (last visited 7 September 2011).

4 ECCC, Internal Rules (revision 3), as revised on 6 March 2009, Rule 23(2). All revisions of the ECCC Internal Rules are available at: http:/Www.ecc.gov.kh/en/document/legal/internal-rules (last visited 7 September 2011).

5 Ibid., e.g. Rules 23(6), 23(11), 24(2).

6 The ECCC consists of a Pre-trial Chamber, Trial Chamber, and Supreme Court Chamber. The Pre-trial and Trial Chambers are composed of five judges (three Cambodian and two international), while the Supreme Court Chamber contains seven judges (four Cambodian and three international). Every decision requires a 'super-majority', meaning an affirmative vote of at least four out of five judges in the Pre-trial and Trial Chambers, and at least five out of seven judges in the Supreme Court Chamber. A Cambodian and an international head the offices of the Co-Investigating Judges and Co-Prosecutors, while each accused is represented by at least two defence lawyers, one Cambodian and one foreign. See Law on The Establishment of Extraordinary Chambers in the Courts of Cambodia for the Prosecution of Crimes Committed During the Period of Democratic Kampuchea, NS/RKM/1004/006, 27 October 2004, Arts. 9, 14, 16, 20, 23. See also ECCC, Internal Rules, above note 4, Rule 22(1) and Rule 22(2), available at: http:// www.ecc.gov.kh/sites/default/files/legal-documents/KR_Law_as_amended_27_Oct_2004_Eng.pdf (last visited 7 September 2011). 
were committed during the Khmer Rouge era, which lasted from 17 April 1975 to 6 January $1979 . .^{7}$ At least 1.7 million people, fully one quarter of the population, were killed or died from some combination of starvation, exhaustion from slave labour, malnutrition, torture, or untreated diseases during the regime. ${ }^{8}$ The Court includes both national and international judges and staff, and has the authority to apply national and international laws. The Duch trial (Case 001) was its first case. Its second case (Case 002), which began in 2011, features three former Khmer Rouge leaders - Ieng Sary (Deputy Prime Minister and Foreign Minister), Khieu Samphan (Head of State), and Nuon Chea (Deputy Secretary of the Communist Party of Kampuchea). ${ }^{9}$ In November 2011, the Trial Chamber ruled that the fourth defendant, Ieng Thirith (Minister of Social Affairs and Action), was unfit to stand trial and that the proceedings against her should be stayed..$^{10}$ The Co-Prosecutors responded by filing an appeal to prevent her release from detention. ${ }^{11} \mathrm{~A}$ third and fourth case (Cases 003 and 004) are still before the Co-Investigating Judges. ${ }^{12}$

One of the ECCC's most innovative steps was the inclusion of civil parties in its proceedings. For the first time in an international criminal trial, victims of mass atrocity were included as civil parties, rather than as mere witnesses. ${ }^{13}$ During the Duch trial, all of the civil parties testified openly and publicly in the courtroom without the use of protective measures, such as image and voice distortion. One civil party, a French citizen of Cambodian descent, testified from France via a teleconference video.

7 Law on the Establishment of Extraordinary Chambers, above note 6, Arts. 1, 3, 4, 5, 6, 7, 8.

8 Estimations of the number of deaths vary. See Craig Etcheson, After the Killing Fields: Lessons from the Cambodian Genocide, Praeger Publishers, Westport, CT, 2005, pp. 107-128.

9 The Trial Chamber held the Initial Hearing in Case 002 on 27-30 June 2011. See, ECCC Public Affairs, 'Trial Chamber announces agenda for Case 002 initial hearing', press release, 16 June 2011, available at: http:/Www.ecc.gov.kh/sites/default/fles/media/ECCC $\% 20$ Press $\% 20$ Release $\% 20-\% 20002 \% 20$ Initial\% 20 Hearing\%20Agenda.pdf (last visited 7 September 2011).

10 See ECCC, Decision on Ieng Thirith's Fitness to Stand Trial, Case File No. 002/19-9-2007/ECCC/TC (Trial Chamber), 17 November 2010, available at: http:/www.ecc.gov.kh/en/document/court/decisionieng-thirith039s-fitness-stand-trial (last visited 27 November 2011).

11 See ECCC, [Corrected 1] Immediate Appeal Against Trial Chamber Decision to Order the Release of Accused Ieng Thirith, Co-Prosecutors, Case File No. 002/19-9-2007/ECCC/TC, 18 November 2011, available at: http:/www.eccc.gov.kh/en/document/court/corrected-1-immediate-appeal-against-trialchamber-decision-order-release-accused-ien (last visited 5 December 2011).

12 The investigation in Cases 003 and 004 have been controversial and have involved several exchanges between the Co-Investigating Judges and the International Co-Prosecutor. See statements by the parties available on the ECCC website at: http:/www.ecc.gov.kh/en/case/topic/286 and http:/www.eccc.gov.kh/ en/case/topic/98 (last visited 27 November 2011). The international Co-Investigating Judge resigned on 9 October 2011. See ECCC Public Affairs, 'Press Release by the International Co-Investigating Judge', 10 October 2011, available at: http:/www.ecc.govkh/en/articles/statement-international-co-investigatingjudge (last visited 27 November 2011).

13 Civil parties have since been included in other criminal tribunals, including the International Criminal Court (ICC) and the Special Tribunal for Lebanon, although the full extent of participatory rights differs from court to court. See, e.g., ICC, Prosecutorv. Thomas Lubanga Dyilo, Case No. ICC-01/04-01/06-1119, 'Decision on Victims' Participation: Public', paras. 93-95 (Trial Chamber I), 18 January, 2008; Rome Statute, Art. 68; ICC, Rules of Procedure and Evidence, Rule 85; Statute of the Special Tribunal for Lebanon, Art. 17; Special Tribunal for Lebanon, Rules of Procedure and Evidence, 10 November 2010, Rule 86. 
During the proceedings, the civil parties spoke freely to the media about their testimonies and the trial process. They also brought moments of great intensity and emotion to the trial, as did the accused, a remarkably complex character who appeared, as one trial observer put it, intelligent, endowed with exceptional memory, well versed in human psychology and displaying great physical and mental resistance'. ${ }^{14}$ Duch and his attorneys (and, occasionally, the judges) sparred with some of the civil parties, challenging their identities and the truthfulness of their testimonies. This, in turn, brought forceful remonstrations from the civil party lawyers. Chaos never prevailed, but there were moments when it appeared that the proceedings would spiral out of control.

In this article, we examine how civil party participation in the Duch trial shaped the trial proceedings, and how the civil parties viewed their interactions with the ECCC. International tribunals are increasingly embracing the notion of victim participation. ${ }^{15}$ However, little research has been conducted into the impact of such participation, either on the administration of justice or on the participants themselves.

As a first step toward remedying this oversight, we studied the transcripts of the Duch trial and, in late 2009, interviewed twenty-one of the twenty-two civil parties who had testified. In August 2010, soon after the verdict was announced, we spoke with seventeen of the twenty-one civil parties whom we had interviewed eight months earlier. In our interviews we probed the meaning that the civil parties had derived from the experience of testifying. What motivated them to testify and what was it like to appear before the accused? What did they think of the behaviour of the judges, prosecutors, and defence attorneys? Was the process fair, the verdict just, and the sentence appropriate? We supplemented their responses with interviews with current and former members of the Cambodia court - judges, prosecutors, and administrators - as well as lawyers, psychologists, and human rights workers who interacted with the civil parties on a regular basis.

By grounding this article in a review of trial transcripts and the views and opinions of a relatively small number of individuals, we run the risk of formulating general conclusions from a limited data set. But our aim is not to provide an overarching theory about the effects of international criminal trials on individual survivors. Instead we intend to explore the process by which a group of direct and indirect victims of the crimes committed at Tuol Sleng prison engaged in an international criminal tribunal and how their experience of testifying affected their lives and their quest for justice.

To set a context for this discussion, we begin with a brief account of the history of victim participation in national and international war crimes trials and the civil law tradition out of which it emerges. We conclude by reflecting on the positive and negative aspects of civil party participation in the Duch trial, and what

14 See Thierry Cruvellier, 'Cambodia: reflections on the Duch trial', in Crimes of War Project, 26 July 2010 , available at: http:/www.crimesofwar.org/commentary/regions/cambodia-reflections-on-the-duch-trial/ (last visited 1 September 2011).

15 Ibid. 
implications our findings may have for future trials at the ECCC, the ICC, and other domestic and international war crimes tribunals.

\section{Civil party participation in war crimes trials}

Victim participation in criminal trials is not a novel phenomenon, but historically it has been more typical in countries with civil law traditions than in those with common law traditions. This distinction is important. The common law system, which is practised in the United Kingdom, the United States, and most former and current Commonwealth countries, tends to focus on the adversarial nature of criminal proceedings: the prosecution and the defence make their cases to the jury and the judge acts mainly as a referee, mediating the process and helping the jury fulfil its fact-finding function. The role of victims in most common law systems is largely limited to that of being a witness. As witnesses, victims can only speak if called on by the prosecution (or defence) and can only answer questions that are posed to them. In some common law countries, such as the United States, victims may also be allowed to provide 'impact statements' during the sentencing phase to make the court aware of facts that could contribute to determining an appropriate sentence.

By contrast, in inquisitorial courts within the civil law system - a system that is predominately utilized by national courts in continental Europe, most of Latin America, many parts of Africa and Asia, and recent adopters of Western legal traditions (for example, Japan)-one or more investigating judges generally supervise the compilation of a dossier (which can include a wider range of evidence than is permitted in common law courts), to which the accused must respond at trial. Curran writes:

the judge has great latitude to bring in any matter that might recreate the past and shed some light on events only indirectly related to the matters at hand, and particularly aspects that might shed light on the moral character and psychological outlook of the perpetrator within the context in which he or she acted. ${ }^{16}$

Unlike the relatively passive role of the common law judge, the inquisitorial judge actively controls the trial's direction and questions witnesses. In such systems, victims may institute proceedings or seek compensation by applying to join the criminal prosecution as a civil petitioner (constitution de partie civile). Victims may also benefit from legal representation, present evidence, cross-examine witnesses, and make closing statements. ${ }^{17}$

Recent international tribunals have had to decide which of these two models to adopt - common law or inquisitorial civil law - or whether to create a

16 Vivian Grosswald Curran, 'Globalization, legal transnationalization and crimes against humanity: the Lipietz case', in American Journal of Comparative Law, Vol. 56, Spring 2008, p. 376.

17 See Charles P. Trumbull IV, 'The victims of victim participation in international criminal proceedings', in Michigan Journal of International Law, Vol. 29, Summer 2008, p. 778. 
hybrid of the two. Because of this, empirical research is desperately needed to help practitioners better understand the impact of each model on victims and the implementation of justice more generally.

\section{Civil party participation in World War II trials}

Little, if anything, is known about the experiences of victims who have testified before international war crimes tribunals. A review of English-language scholarship covering the hundreds of war crimes trials that followed World War II reveals not a single empirical study of victims and their perceptions of the trial process. ${ }^{18}$ It is tempting to dismiss this omission as scholarly lack of interest or oversight. But it seems more likely that the experiences of victims were overlooked in the post-World War II years because they did not factor into the larger public debates at the time, especially in Germany and Japan, where the very legitimacy of the trials was hotly contested. ${ }^{19}$ The French sociologist Annette Wieviorka suggests that this paucity can be attributed, in part, to the reluctance of many Holocaust survivors in the years immediately following World War II to speak publicly about the atrocities that they experienced ${ }^{20}$ And, unlike today, there were few formal support systems for survivors actively encouraging them to speak publicly about past abuses.

It was not until the trial of the SS officer Adolf Eichmann that a forum was created for victims to share their memories of the Holocaust with the world. The Eichmann trial, according to Wieviorka, marked the advent of an 'era of testimony' for victims of mass atrocities that continues to this day. ${ }^{21}$ She points to the pedagogical and commemorative role that victim-witnesses played in having, in the words of the prosecutor, Attorney-General Gideon Hausner, lit 'a spark in the frigid chamber which we know as history. ${ }^{22}$ But not all observers of the Eichmann proceedings thought these new functions for war crimes trials were necessarily a good thing.

In Eichmann in Jerusalem, the writer and philosopher Hannah Arendt betrays her impatience with the 'endless sessions' of survivor testimonies. The victims' speeches occupied half the court's agenda and, at times, 'degenerated into a bloody show, "a rudderless ship tossed about on the waves"', where 'witness followed witness and horror was piled upon horror'. ${ }^{23}$ She argues that, while every

18 Neither of the two major bibliographies on war crimes trials immediately following World War II contains any references to studies of victims and witnesses. See Norman E. Tutorow (ed.), War Crimes, War Criminals, and War Crimes Trials: An Annotated Bibliography and Source Book, Greenwood Press, New York, 1986; Inge S. Neumann (ed.), European War Crimes Trials: A Bibliography, Greenwood Press, New York, 1951.

19 The Allied Forces were more interested in vilifying the German and Japanese leaders in the eyes of their own people than in creating a forum for victims to tell their stories. See, for example, Telford Taylor, The Anatomy of the Nuremberg Trials: A Personal Memoir, Alfred A. Knopf, New York, 1992.

20 See Annette Wieviorka, L'Ére du témoin, Plon, Paris, 1998.

21 Ibid., p. 97.

22 Ibid.

23 Hannah Arendt, Eichmann in Jerusalem: A Report on the Banality of Evil, Penguin Books, New York, 1977 , pp. 8-9. 
effort must be made to vindicate the suffering of victims during war crimes proceedings, it must not be forgotten that

a trial resembles a play in that both begin and end with the doer, not with the victim ... In the center of a trial can only be the one who did - in this respect, he is like the hero in the play - and if he suffers, he must suffer for what he has done, not for what he has caused others to suffer. ${ }^{24}$

Thus, vindicating victims must be subordinated to the demands of a fair trial, one in which it is the accused who plays protagonist.

In recent decades, France has received the most attention for its use of victim participation in three prominent trials of alleged Nazi war criminals and sympathizers. ${ }^{25}$ Klaus Barbie (head of the Gestapo in Lyon), Paul Touvier (leader of a Vichy-run paramilitary group), and Maurice Papon (a police official in the Prefecture of Bordeaux) were the first such defendants to find themselves subject to French justice. In the 1987 Barbie case, the court defined the term 'victim' fairly broadly, thereby establishing an expansive foundation for civil party participation in subsequent trials. In the words of one set of commentators, victims included 'not only the direct objects of systematic racial or religious persecution, but also those who opposed such persecution by any means. Thus, [even] Resistance members, as soldiers fighting Nazism ... could be deemed victims of crimes against humanity. ${ }^{26}$

The 1994 Touvier trial, held just outside Paris, similarly embraced a broad definition of 'victim', becoming notable for its extensive civil party participation. By the end of the trial, Touvier and his attorneys had faced not only the public prosecutor but also a bevy of thirty-four civil party lawyers representing between fifty and eighty victims and victim groups. As with the Eichmann trial, this remarkable level of victim participation resulted in sharp criticism, the trial quickly descending into what some have described as 'an extraordinary spectacle'. ${ }^{27}$

The third trial was that of Maurice Papon, who was convicted in 1998 for his role in ordering the arrest and deportation of 1,690 Jews to extermination camps during the Nazi occupation of France. ${ }^{28}$ At least one commentator has suggested that Papon would never have been prosecuted but for civil party involvement:

[His] nearly 40 years of service at the highest levels of the French civil service subsequent to the war... would appear to have demonstrated that his reputation had been rehabilitated significantly if not completely in the higher

24 Ibid., p. 261.

25 See Thierry Cruvellier, 'Civil party participation and representation: a few other experiments at a glimpse', International Center for Transitional Justice, 2009, which provides an overview of civil party participation in domestic war crimes proceedings in several countries.

26 Michael E. Tigar, Susan C. Casey, Isabelle Giordani, and Sivakumaren Mardemootoo, 'Paul Touvier and the crime against humanity', in Texas International Law Journal, Vol. 30, 1995, p. 295 (discussing the history of the Barbie case and its influence on Touvier's subsequent trial).

27 Ibid., p. 299.

28 Whitney R. Harris, 'A world of peace and justice under the rule of law: from Nuremberg to the International Criminal Court', in Washington University Global Studies Law Review, Vol. 6, 2007, pp. 689 and 697. See also Richard H. Weisberg, 'The risks of adjudicating Vichy', in Roger Williams University Law Review, Vol. 5, 1999, p. 127. 
circles of French society. It was the insistent efforts by his fellow citizens whose families had suffered due to Papon's actions that countered that process of rehabilitation to finally force the case to come forward. ${ }^{29}$

Another commentator has noted the crucial role that civil parties played in extending liability for Papon's actions to France itself: the Papon case was 'the first to hold the French state directly liable [to victims] for acts of the Vichy government'. ${ }^{30}$ Still, the trial was not without controversy. Many of the civil parties had nothing to say about Maurice Papon himself and failed to draw any direct link between the fate of their family members and the actions of the former Vichy bureaucrat. $^{31}$

\section{Victim participation in recent international criminal tribunals}

Since the early 1990s, a number of national and international victims rights and human rights organizations have lobbied to ensure that victims' participatory rights would be embedded in the founding documents of the ICC and other international criminal tribunals. This movement, though viewed with scepticism in some legal circles, was fuelled by four factors that had emerged over several decades. ${ }^{32}$

\section{Victims' rights movement}

The first factor dates back to the rise of a victims' rights movement in Great Britain, New Zealand, and several other common law countries in the 1960s. Legislators in these countries enacted a series of laws to protect and compensate crime victims, especially victims of rape and child abuse. ${ }^{33}$ Over the next three decades, the existence of such laws, coupled with new research on the psychological effects of trauma, ${ }^{34}$ would help to generate a second wave of legislation aimed at providing victim-witnesses with specific rights in criminal proceedings. In 1990, lobbying efforts in the United States led to the adoption of a victims' bill of rights, which instructs federal prosecutors and law enforcement officers that victims of crime should be regarded as active and engaged participants in - not merely auxiliaries

29 Benjamin G. Davis, 'Refluat stercus: a citizen's view of criminal prosecution in U.S. domestic courts of high-level U.S. civilian authority and military generals for torture and cruel, inhuman or degrading treatment', in Saint John's Journal of Legal Commentary, Vol. 23, 2008, p. 544

30 See V. Grosswald Curran, above note 16, p. 373.

31 See Nancy Wood, 'The Papon trial in an "era of testimony", in Richard J. Golsan (ed.), The Papon Affair: Memory and Justice on Trial, Routledge, New York, 2000, p. 97.

32 See C. P. Trumbull IV, above note 17, p. 778; and Eric Stover, The Witnesses: War Crimes and the Promise of Justice in The Hague, University of Pennsylvania Press, Philadelphia, PA, 2005, pp. 17-32.

33 In common law countries, New Zealand adopted the first victim's compensation law in 1963, followed by England in 1964. See William Doerner and Steven Lab, Victimology, 2nd edition, Anderson, Cincinnati, $\mathrm{OH}, 1988$, p. 18. See also Joanna Shapland, Jon Willmore, and Peter Duff, Victims in the Criminal Justice System, Gower, Aldershot, Hampshire, 1985, p. 175.

34 See, e.g., Judith Lewis Herman, Trauma and Recovery: The Aftermath of Violence-From Domestic Abuse to Political Terror, Basic Books, New York, 1992. 
to - the criminal justice system. ${ }^{35}$ The bill of rights requires that victims be kept informed about the progress of their case, be treated in a dignified manner, and be reasonably protected from the accused. ${ }^{36}$ In the United Kingdom, the Victims' Charter, enacted in 1996, provides victims with a number of services throughout the criminal process and requires the prosecutor to consider the victim's views when deciding whether to prosecute. ${ }^{37}$ Similar legislation was adopted by the Council of Europe at the beginning of the twenty-first century. ${ }^{38}$

\section{UN initiatives}

The second contributing factor was the impetus behind several UN initiatives designed to address the plight of crime victims at the international level. One of the most significant initiatives was the Declaration of Basic Principles of Justice for Victims of Crimes and Abuse of Power, adopted by the UN General Assembly in $1985 .{ }^{39}$ Hailed as an international Magna Carta for crime victims, the declaration sets out basic principles of justice, including the right of victims to have access to the judicial process and receive prompt redress for the harms they have suffered. Six years later, Theo van Boven, then UN Special Rapporteur on the prevention of discrimination and protection of minorities, created a set of basic principles to guide the provision of reparations to victims of human rights violations. ${ }^{40}$ The 'van Boven Principles', as they are commonly called, guided the victim-centred approach ultimately adopted by the drafters of the ICC's Rome Statute. ${ }^{41}$

\section{Case law of regional human rights courts}

The third contributing factor has been three decades of case law, developed by treaty-based regional human rights courts that have interpreted human rights conventions as conferring legal standing on victims. Some recent decisions by the

35 See the Crime Control Act of 1990 (42 U.S.C. $\$ \$ 10606-10607$ ) and the Victims' Rights Clarification Act of 1977 (18 U.S.C. $\$ 3510)$.

36 In 2004, Congress passed the Crime Victims' Rights Act (18 U.S.C. $\$ 3771$ ), which guaranteed victims the right to 'reasonably be heard at any public proceeding in the district court involving release, plea, sentencing, or parole proceedings'.

37 Craig Bradley (ed.), Criminal Procedure: A Worldwide Study, 2nd edition, Carolina Academic Press, Durham, NC, 2007 , p. 45.

38 See Council of Europe, Council Framework Decision of 15 March 2001 on the Standing of Victims of Crime in Criminal Proceedings (2001/220/JHA) OJ, L82, 22 March 2001, and Commission of the European Communities, Council Directive on Compensation to Crime Victims, European Commission, Brussels, 2002 , p. 562.

39 United Nations Declaration of Basic Principles of Justice for Victims of Crime and Abuse of Power, UN General Assembly Resolution 40/34 of 29 November 1985, available at: hitp:/www.un.org/documents/ga/ res/40/a40r034.htm (last visited 25 August 2010).

40 Basic Principles and Guidelines on the Right to a Remedy and Reparation for Victims of Gross Violations of International Human Rights Law and Serious Violations of International Humanitarian Law, adopted by UN General Assembly Resolution 60/147 of 16 December 2005.

41 See Theo van Boven, 'The position of the victim in the Statute of the International Criminal Court', in H. von Hebel, J. G. Lammers, and J. Schukking (eds), Reflections on the International Criminal Court: Essays in Memory of Adriaan Bos, T.M.C. Asser Press, The Hague, 1999, p. 81. 
European Court of Human Rights (ECHR), for example, specify that victims have a right to be kept informed of trial proceedings, provided with information about the investigation and trial, and allowed access to relevant documents to ensure meaningful participation. ${ }^{42}$ The ECHR stopped short of granting victims participatory rights in criminal proceedings, but the court has supported a principle later enshrined in the Rome Statute, namely that victims should have significant access to the criminal justice process and receive compensation for their suffering. ${ }^{43}$

\section{Criticisms of international criminal tribunals}

The fourth factor contributing to the rise of victims' rights has been response to the criticisms lodged - rightly or wrongly - against the International Tribunal for the Former Yugoslavia (ICTY) and the International Criminal Tribunal for Rwanda (ICTR) for their failure to consider victims' needs. For example, neither tribunal provides victims with the right to apply for reparations or participate in proceedings beyond testifying as witnesses. Critics argue that these omissions essentially objectify victims and turn them into mere instruments for securing convictions. ${ }^{44}$

\section{Victim participation at the International Criminal Court}

Unlike the statutes underlying the tribunals for Rwanda and the former Yugoslavia, the Rome Statute of the International Criminal Court (ICC), adopted in 1998, gives victims an innovative role as witnesses, courtroom participants, and reparations beneficiaries. ${ }^{45}$ The Rome Statute provides victims with extensive procedural rights, including the right to be heard by judicial authorities regarding the decision to authorize an investigation, the admissibility of a case, and issues that affect their personal interests, so long as the presentation is done in a manner which is not prejudicial to or inconsistent with the rights of the accused and a fair and impartial trial'. ${ }^{46}$ As such, the Statute recognizes that the ICC has 'not only a punitive but also a restorative function', reflecting the 'growing international consensus that participation and reparations play an important role in achieving justice for victims'. ${ }^{47}$

Victim participation provisions have caused significant dissension among jurists, activists, and scholars, who often split along common law versus civil law

42 Raquel Aldana-Pindell, 'In vindication of justiciable victims' rights to truth and justice for state-sponsored crimes', in Vanderbilt Journal of Transnational Law, Vol. 35, No. 5, 2002, pp. 1419-1422, 1434-1436.

43 Ibid., pp. 1419-1422.

44 C. P. Trumbull IV, above note 17, p. 788.

45 Most victims participate in court proceedings through legal representatives, but in the ICC's first trial three victim-participants addressed the Court directly. See Eric Stover, Camille Crittenden, Alexa Koenig, Victor Peskin, and Tracey Gurd, 'The impact of the Rome Statute system on victims and affected communities', paper delivered at the Review Conference of the Rome Statute, International Criminal Court, Kampala, Uganda, 30 May 2010 (RC/ST/V/INF.4).

46 Rome Statute of the International Criminal Court, 17 July 1998, A/CONF.183/9, Art. 68.

47 See ICC, Report of the Court on the Strategy in Relation to Victims, ICC-ASP/8/45, 10 November 2009, Introduction, para. 3 . 
lines. On one side are those who argue that by providing victims with expansive participatory rights the ICC and other international tribunals will help restore victims' dignity, contribute to their 'healing' and rehabilitation, and bring to light facts and evidence that may not otherwise emerge. ${ }^{48}$ On the opposing side are those who fear that such participatory rights will run roughshod over a defendant's right to a fair trial; prolong proceedings, thus increasing the cost of prosecution; hinder the prosecutor's ability to conduct a focused investigation; and provide legal recognition to certain categories of victims and not others, thereby limiting any access to justice. On the last point, one commentator argues that the cost for 'unrecognized victims' will be extensive as '[c]rimes falling within the ICC's jurisdiction may involve hundreds of thousands of victims, most of whom will not be legally recognized by the Court'. ${ }^{4}$

\section{Civil party participation at the Extraordinary Chambers in the Courts of Cambodia}

While victim participation had occurred in national war crimes trials in France and a few other countries, the Duch trial in the ECCC marked the first time that an international tribunal had afforded victims the opportunity of joining the proceedings as civil parties. The ECCC's founding document ${ }^{50}$ contained no provision for victim participation, but the Court's Internal Rules, adopted two years later, included a right for direct participation in court proceedings similar to that in the ICC's Rome Statute. ${ }^{51}$ However, while the ICC allows victims to participate in proceedings, the ECCC refers to some victims not as participants but as parties civiles, or 'civil parties'. ${ }^{2}$ A civil party is an actual party to the criminal proceedings and thus shares many of the same procedural rights as the defence and prosecution. Civil parties are permitted, through their lawyers, to address the court from the commencement of the proceeding - unlike witnesses, who only address the court at trial. Civil parties are usually able to question witnesses, experts, and the accused. Finally, the Court's Internal Rules specify that the purpose of the civil parties is twofold: to support the prosecution and to secure collective and moral reparations, ${ }^{53}$

48 For an overview of the arguments commonly put for and against victim participation in international criminal tribunals, see C. P. Trumbull IV, above note 17, pp. 802-805.

49 Ibid., p. 811; for arguments against victim participation in international trials see pp. 805-818.

50 Agreement between the United Nations and the Royal Government of Cambodia concerning the prosecution under Cambodian Law of crimes committed during the period of Democratic Kampuchea, 17 March 2003, approved by General Assembly Resolution 57/228 B, 22 May 2003, Annex.

51 See James P. Bair, 'From the numbers who died to those who survived: victim participation in the Extraordinary Chambers in the Courts of Cambodia', in Harvard Law Review, Vol. 31, 2009, pp. 507-508, 520; see also ECCC, Internal Rules, above note 4, Rules 23(1), 23(3), 23(7), 23(8).

52 See Jenia Iontcheva Turner, 'Decision on civil party participation in provisional detention appeals', in David J. Bederman (ed.), 'International decision', in American Journal of International Law, Vol. 103, No. 1, 2009, pp. 116-118; see also ECCC, Internal Rules, above note 4, Rules 23(1), 23(2), 23(3), 23(4), $23(5), 23(6)$.

53 ECCC, Internal Rules, above note 4, Rule 23(1). 
which eliminates the need for individual compensation for the potentially overwhelming number of people victimized by the Khmer Rouge.

The ECCC draws a clear distinction between 'victims' who are complainants and victims who are 'civil parties'. Both categories can participate in ECCC proceedings, but the scope of their role differs. A complainant is a person who suffered, witnessed, or is aware of any crimes committed under the Khmer Rouge and chooses to submit a complaint to the Co-Prosecutors. The CoProsecutors, in turn, may use this information to shape their investigations. ${ }^{54} \mathrm{~A}$ civil party is someone who was directly affected by one or more factual situations under investigation by the Court. ${ }^{55}$ Whereas a complainant's role is limited to bringing to the Co-Prosecutor's attention crimes under the regime, civil parties are active participants in every step of the judicial proceedings. The Chamber can later withdraw an individual's civil party status if it believes sufficient doubt has been raised about his or her status as either a direct victim or a relative or dependent of a victim. ${ }^{56}$

During Case 001, it was not the ECCC's under-resourced Victims Unit, established to assist victims file complaints and civil party applications, ${ }^{57}$ but Cambodian human rights organizations ${ }^{58}$ and civil party lawyers who led the effort to inform the Cambodian public about civil party participation at the ECCC, find legal representatives for the civil parties, and develop a system for managing the applications. ${ }^{59}$ Human rights groups undertook these projects with very limited guidance or assistance from the ECCC. In the end, these organizations became involved in nearly every aspect of the civil party process: informing victims of their

54 Ibid., Rules 49(2), 49(4).

55 At the time of the first trial, civil party applications were made to the Office of the Co-Investigating Judges (OCIJ) or the Trial Chamber and not to the Co-Prosecutors: see ECCC, Internal Rules, above note 4, Rules 23(3), 23(4). Since February 2010, civil party applications have been received by OCIJ only; see ECCC, Internal Rules (revision 5), as amended 9 February 2010, Rule 23 bis (2), Rule 23 bis (3). Situations under investigation are defined by facts presented by the Co-Prosecutors in Introductory or Supplementary Submissions: see ECCC, Internal Rules, above note 4, Rules 53(1), 55(2).

56 See for example, ECCC, Case File No. 001/18-7-2007/ECCC/TC, above note 3, paras. 639-649.

57 ECCC, Internal Rules, above note 4, Rule 12. Since February 2010, the Victims Unit has been renamed the Victims Support Section: see ECCC, Internal Rules (revision 5), above note 55, Rule 12.

58 Five Cambodian groups - the Documentation Center of Cambodia (DC-CAM); the Cambodia Human Rights and Development Organization (ADHOC); the Khmer Institute for Democracy (KID); the Center for Social Development/Center for Justice and Reconciliation (CSD/CJR), whose focus would later be on the second Khmer Rouge case, Case 002; and the Khmer Kampuchea Krom Human Rights Association (KKKHRA) - took the lead in distributing and helping applicants fill in the forms. Two legal aid groups - the Cambodian Defender Project (CDP) and Legal Aid of Cambodia (LAC) - headed up the task of retaining lawyers for the civil parties, while the Cambodian Human Rights Action Committee (CHRAC), an umbrella organization for local human rights and aid groups, developed a database to track victim complaints and civil party applications.

59 The German Development Service (DED), Civil Peace Services (ZFD), and the French and the British embassies, for example, played an essential role in supporting these legal assistance projects. See DED/ GIZ, Projects, Civil Peace Service, available at: http:/kambodscha.ded.de/en/projects/civil-peace-service. html; ambassade de France à Phnom Penh, la France au Cambodge, 'Soutien de la France à l'association "Avocats sans frontières"', available at: http:/www.ambafrance-kh.org/spip.php?article1247; and British Embassy in Phnom Penh, Working with Cambodia, Khmer Rouge Tribunal, available at: http:// ukincambodia.fco.gov.uk/en/about-us/working-with-cambodia/khmer-rouge-tribunal/ (all websites last visited 7 September 2011). 
rights; holding group meetings to answer questions; helping applicants fill in the requisite forms (a process that could often take hours and, in some cases, days); ${ }^{60}$ compiling and entering information from the forms into a database; sending the forms to the ECCC; and following up with the civil party applicants. The important role that the non-governmental organizations (NGOs) played is borne out by the interviews that we conducted: all of the civil parties said that their primary connection to the court was not through the Victims Unit but through their lawyers and local NGOs.

In November 2008, the German Foreign Office awarded the ECCC a grant of 1.5 million Euros to bolster the court's victim support services ${ }^{61}$ One of the Court's most important victim-related initiatives was to contract with the Transcultural Psychosocial Organization (TPO), a local mental health organization, to provide psychological support to civil parties, including a national hotline. TPO staff also offer civil parties support and counselling inside and outside the courtroom and, if summoned by the presiding judge, sit next to anyone who becomes agitated or overly emotional on the witness stand. ${ }^{62}$

\section{Civil party participants and their experiences}

What has been the experience of civil parties who have testified at the ECCC? In November and December 2009, we interviewed twenty-one of the twenty-two civil parties who testified in the Duch trial. ${ }^{63}$ Of these, seventeen were Cambodian citizens, three were French citizens (two of whom were of Cambodian descent), and one was a citizen of New Zealand. Eleven of the participants were male and ten were female. The youngest was 33 years old and the oldest was 79 ; most respondents were in their fifties. All but one of the interviews took place in Cambodia; the exception was a phone interview from Phnom Penh with a civil party living in New Zealand. The interviews were conducted at the close of the trial but before the announcement of the verdict. After the Chamber announced its judgment on 26 July 2010, we asked seventeen of the twenty-one civil parties to whom we had spoken in late 2009 about their views of the verdict.

\section{Coming forward to testify}

Most of the respondents we interviewed said that they had not fully thought through how becoming a civil party would affect them. Some entered the process

60 Practice direction, including the application form, can be downloaded from the ECCC website, available at: http//www.ecc.gov.kh/sites/default/fles/legal-documents/PD_Victims_Participation_rev1_En.pdf (last visited 6 September 2011).

61 See ECCC, Public Affairs, 'ECCC issues media alert on signing ceremony of German contribution', 6 November 2008.

62 TPO also offers individual and group therapy sessions to civil parties: see ECCC Court Report, Issue 12, Phnom Penh, February 2010, p. 10.

63 One of the twenty-two civil parties was in the hospital and unable to receive visitors. 
with some reluctance, largely because they feared speaking publicly about painful memories that had burrowed deep into their psyches for decades. One respondent, a 54-year-old businessman whose brother perished in Tuol Sleng, put it this way: 'I do not like being under the spotlight, to be forced to talk about myself, to speak in front of other people. I consider suffering to be personal and discreet'.64

Some respondents had never previously revealed to their spouses or children how they had been treated in prison. 'I had kept my whole story a secret', one person said. 'My wife knew I had been a prisoner, but, for 30 years, I never specified exactly where I had been detained and what I had experienced'.65 The former prisoner's wife would learn these details as she sat with her children watching her husband testify on television.

Tuol Sleng survivor Chin Met said that her initial reluctance to testify was tethered to a life of secrecy in which keeping quiet or revealing as little as possible had helped her survive. She told the court that her father and mother had died when she was young and that she had been sent to a village in Khampong Thom to live with her grandparents. ${ }^{66}$ One day Khmer Rouge soldiers came to her village, and she was pressed into service. Later, her superiors discovered an incriminating photograph of her father, who had been a Sihanouk government official, in her possessions. Chin Met was arrested and sent to Tuol Sleng, where she was processed, and then transferred to the re-education camp at Prey Sar. Unaware of her fate, her family held a death ceremony for her.

After her release, Chin Met survived by selling items that she scavenged from a garbage heap. Following the fall of the Khmer Rouge regime, she returned to her village, where she said nothing of her time in captivity, fearing that her family and community would shun her. 'I just wanted to hide it', she said. But that changed in 2003, when she received a copy of her file from Tuol Sleng prison. 'At that time I didn't realize I was a S-21 survivor.... I was trying to forget about the past'. ${ }^{67}$ Four years later, a group of her neighbours visited Tuol Sleng and discovered two photographs of her on display at the museum in the former prison. 'I was given two photographs', she recalled, 'and I was asked whether [they were] real photos of myself.' I said: 'Yes, but I don't want to anything else about that because I [don't] want to recall all my suffering. ${ }^{\text {'68 }}$

As one of the only female survivors of Tuol Sleng, Chin Met was an invaluable asset to the court. A local NGO provided counselling for her and directed

64 Interview, 24 November 2009.

65 Interview, 26 November 2009.

66 See ECCC, Transcript of Trial Proceedings - Kaing Guek Eav 'Duch', Case File No. 001/18-07-2007ECCCC/TC, 8 July 2009, Trial Day 41, pp. 42-103, available at: htp:/www.ecc.gov.kh/en/documents/ court/transcript-proceedings-\%E2\%80\%9Cduch\%E2\%80\%9D-trial-trial-day-41 (last visited 7 July 2011 ).

67 Interview with Chin Met, 14 November 2009.

68 See Trial Day 41, above note 66, p. 93. 
her to the ECCC's victim unit. ${ }^{69}$ 'Later I received a phone call to meet with lawyers [from Avocats Sans Frontières]', she recalled.

Their office was on the other side of the river in an area of the city I didn't know very well. So I thought: 'Oh dear, I'm going to get myself into more trouble.' ... The night before the meeting I couldn't sleep. The next morning I took a tuk tuk and the lawyers reimbursed me. They explained how the civil party process worked and then let me tell my story. They were encouraging, and asked if I felt strong enough to testify. They really showed me the way. ${ }^{70}$

\section{Motivation to testify}

Just after World War II, George Orwell wrote a short essay on war crimes trials titled 'Revenge is sour'. In it, he argued that the

whole idea of revenge and punishment is a childish day-dream. Properly speaking, there is no such thing as revenge. Revenge is an act which you want to commit when you are powerless and because you are powerless: as soon as the sense of impotence is removed, the desire evaporates also. ${ }^{71}$

Revenge is also potentially self-defeating, if not for the avenger then potentially for future generations of his or her family. As a Chinese proverb warns, 'If you seek revenge, dig two graves.'

Under Duch's command, interrogators at Tuol Sleng - which means 'hill of poisonous trees' in the Khmer language-committed unspeakable atrocities, including the pulling of fingernails, holding victims' heads under water, and bleeding prisoners to death. The vast majority of prisoners were eventually executed and buried in mass graves. Given these horrible crimes, one would think that Duch's victims would have expressed strong desires for revenge. Yet only one civil party explicitly said that she would kill Duch if given the chance. While none of those whom we interviewed said that they would ever forgive Duch for his crimes, ${ }^{72}$ most expressed one or more of four motivations for testifying: a need to know more about what had happened to themselves and their loved ones, a desire to pursue 'justice', a need to tell their story, and a need to educate the world about the Khmer Rouge regime.

69 See Center for Social Development, 'CSD discovers only woman survivor of Tuol Sleng', Press Release, 1 August 2007.

70 Interview with Chin Met, above note 67.

71 Quoted in George Parker, 'Trials', in New Yorker, 5 January 2004, p. 5.

72 The vast majority of respondents in two, earlier, studies of ICTY victim-witnesses also said that they could never forgive those responsible for their own suffering or the suffering of family members. See E. Stover, above note 32, pp. 75-76. See also Gabriela Mischkowski and Gorana Mlinarevic, "... And That it Does Not Happen to Anyone Anywhere in the World": The Trouble with Rape Trials - Views of Witnesses, Prosecutors, and Judges on Prosecuting Sexualised Violence during the War in the Former Yugoslavia, Medica Mondiale, December 2009, p. 53, available at: http:/www.medicamondiale.org/fileadmin/content/ 07_Infothek/Gerechtigkeit/medica_mondiale_Zeuginnenstudie_englisch_december_2009.pdf (last visited 19 December 2011). 


\section{The need to know}

First and foremost, civil parties wanted to confront Duch in the courtroom and force him to divulge details about the treatment of their deceased relatives, and accept responsibility for his crimes. Ou Savrith echoed the sentiments of other civil parties:

I wanted to know what exactly happened inside of S-21, to find out how prisoners were interrogated and tortured. I wanted to know what my brother suffered, to live what he had experienced. This was my way of helping to alleviate his suffering. ${ }^{73}$

Another respondent put it this way: 'Of all of my family I am the only survivor. So I wanted Duch to tell me what exactly had happened to my family. Who gave the orders to arrest them. And who ordered them to be killed'.$^{74}$ Many wanted Duch to tell them where the remains of their loved ones had been interred so that they could gather soil from the spot and perform a proper death ceremony at their homes. Some had already created shrines in anticipation of receiving some tangible evidence of their relative's burial.

This palpable need for details about a loved one's fate - however painful reverberates in families of the disappeared around the world, regardless of cultural or political context. ${ }^{75}$ Unlike those known to have died and been mourned, the disappeared remain alive for those left behind. When forensic excavations of mass graves begin, family members will remain at the burial sites for days and weeks, hoping to learn some new and tangible fact about the fate of their missing relatives. The Harvard psychiatrist Richard Mollica writes, 'In many cultures the disappeared are seen as souls trapped in a shadow world between the living and the dead, endlessly searching for a peaceful death. Until they are found, they cannot escape their anguish and pain'. ${ }^{76}$

For many civil parties in the Duch case, Tuol Sleng represents a tomb frozen in time that possesses both the spiritual and the physical remnants (in this case, files and photographs) of those who suffered and died there. Just like the many relatives who placed their hope in the forensic teams exhuming the remains of the disappeared in Guatemala and Bosnia, many civil parties believe that the ECCC can help them find some trace in the remnants of Tuol Sleng, bringing them closer to their disappeared relatives and, in some cases, setting their loved ones free from a world of limbo, as Neth Phally did when he displayed the photo of his deceased brother in the courtroom.

Ten of the fourteen civil parties whose family members had perished at S-21, including all of those living outside Cambodia, said that the opportunity to

73 Interview with Ou Savrith, 24 November 2009.

74 Interview, 17 November 2009.

75 See Christopher Joyce and Eric Stover, Witnesses from the Grave: The Stories Bones Tell, Little, Brown \& Company, Boston, MA, 1991.

76 Richard F. Mollica, Healing Invisible Wounds: Paths to Hope and Recovery in a Violent World, Vanderbilt University Press, Nashville, TN, 2006, p. 78. 
confront Duch in the courtroom represented a pivotal moment in their quest to uncover the truth about the fate of their loved ones. Martine Lefeuvre, whose husband perished in Tuol Sleng, recalled that 'I believed one day there would be a court. I knew a group of lawyers and organizations would rise up and make sure those crimes would not go unpunished. And I was right'. In the fall of 2008, Lefeuvre discovered through a friend of her daughter that Avocats Sans Frontières was accepting civil party applications. 'Suddenly, I thought, my God, everything is possible. I hadn't climbed a step, I had ascended a temple!'77

Lefeuvre and her daughter, Ouk Neary, like other civil parties whom we interviewed, described being 'compelled' or 'driven' to uncover the truth about their deceased loved ones. 'I spent my entire life trying to come closer to the truth, the truth which the accused thinks he owns and of which I was deprived', Ouk Neary told the court. 'I wanted to know what my history was, I wanted to know what the truth was and this quest I undertook on my own ...? ${ }^{78}$

Ouk Neary's first memory of her father, Ouk Ket, was learning of his death in 1979 when she was only 4 years old. Two years earlier, the Cambodian foreign services had recalled Ouk Ket, a diplomat in the Cambodian Embassy in Senegal, to Phnom Penh. He died in Tuol Sleng prison five months later, while his family was in France. In 1991, Neary, then 16, travelled to Phnom Penh with her mother and older brother and visited Tuol Sleng. Walking through the detention cells in the oppressive heat, they eventually arrived at a series of open rooms, their walls lined with portraits of prisoners who had been tortured and executed. They looked in vain for a photograph of Ouk Ket. Two weeks later, they returned to the prison and gained access to the room where the archives were stored. Leafing through the files, they uncovered a folder marked 'December 1977' and found Ouk Ket's name on a list of 301 people designated for execution. 'That day', Ouk Neary told the court, 'is the day when a drop of poison came to me, and I have never since... stopped trying to find out what happened [to my father]'.79

\section{The quest for justice}

When asked about their motivations for testifying, all of the civil parties mentioned, often repeatedly, their desire to obtain justice for themselves, their families, and their deceased relatives. For the most part, they grounded their need to testify in personal and intrinsic terms rather than in feeling a responsibility to perform a universal good for all Cambodians or all humanity, although such sentiments were not completely absent. The artist Bou Meng, who survived his captivity in Tuol Sleng but lost his wife, said that he testified for 'my benefit and that of my wife... and I wanted Duch to accept responsibility for our 
suffering' ${ }^{80}$ A fellow S-21 survivor, Chum Mey, told the court that, after receiving the summons to testify,

I was so excited, so happy. I was so clear in my mind that I would testify to shed light before this Chamber, to tell the truth. I felt so relieved ... my mind was so disturbed. ... I wanted to get it out of my chest. ${ }^{81}$

Chum Neou said that she testified on behalf of her husband, who had perished at Tuol Sleng, and her seven-month-old son, who had died of starvation while she and her child were detained in a Khmer Rouge 're-education' camp and a branch of S-21. Today Chum Neou lives in a rural Cambodian house on stilts, in a town two hours' drive from Phnom Penh. She has lived there for nearly thirty years but rarely talks about her time in prison or the time that she spent as a Khmer Rouge cadre, ${ }^{82}$ at least to strangers. The walls of her home bear numerous photographs of herself throughout her life but none of her family members.

When the war ended, Chum Neou returned to her village, only to find herself shunned because she had voluntarily joined the Khmer Rouge. Neou told the court:

My mother was so furious when I met her. She said [it was] because of me that her husband had died and this [was] a great pain inflicted on me... I [also] knelt down before my aunt to ask her forgiveness for the loss of her husband, but she would not accept it and she was my blood relative. And here I am before the Chamber and I cannot accept the apology made by the accused.... just one word of apology by the accused in the Chamber cannot be accepted... I lodged a complaint [before this court] to be a responsible person on behalf of my relatives who were victims of the crimes of that regime, to prove that I am not a member of the Khmer Rouge and I am responsible and that I am loyal to the nation. And that I felt betrayed by that group. ${ }^{83}$

\section{The need to tell one's story}

In his memoirs of the Holocaust, Primo Levi frequently suggests that bearing witness to mass atrocity is both an act of narration - a trajectory of cause and

80 Interview with Bou Meng, 15 November 2009.

81 See ECCC, Transcript of Trial Proceedings - Kaing Guek Eav 'Duch', Case File No. 001/18-07-2007ECCCC/TC, 30 June 2009, Trial Day 36, pp. 66-67, available at: http:/www.ecc.gov.kh/en/documents/ court/transcript-procedings-\%E2\%80\%9Cduch $\% \mathrm{E} 2 \% 80 \% 9 \mathrm{D}$-trial-trial-day-36 (last visited 7 July 2011 ).

82 In addition to non-Khmer Rouge, S-21 held a large number, slightly over $78 \%$, of those Khmer Rouge cadres who were accused of being spies or traitors. They came from either a Democratic Kampuchea government office or a military unit. See ECCC, Public Information by the Co-Prosecutors Pursuant to Rule 54 Concerning their Rule 66 Final Submission Regarding Kaing Guek Eav alias 'Duch', OCP, 18 July 2008, Criminal Case File 002/14-08-2006/ECCC/OCP, para. 81, available at: http:/www.ecc.gov.kh/sites/ default/files/documents/courtdoc/Rule_54_Public_Information_re_Final_Submission.pdf (last visited 8 September 2011). For detailed explanations of S-21 prisoners, see David Chandler, Voices from S-21: Terror and History in Pol Pot's Secret Prison, University of California Press, Berkeley, CA, 1999, pp. 41-76.

83 See ECCC, Transcript of Trial Proceedings - Kaing Guek Eav 'Duch', Case File No. 001/18-07-2007ECCCC/TC, 24 August 2009, Trial Day 63, pp. 42-43, available at: http:/www.ecc.gov.kh/en/documents/ court/transcript-procedings-\%E2\%80\%9Cduch $\% \mathrm{E} 2 \% 80 \% 9 \mathrm{D}$-trial-trial-day-63 (last visited 7 July 2011 ). 
effect - and a form of survivorship. ${ }^{84}$ Similarly, the psychoanalyst Dori Laub argues that survivors need not 'only to survive so they can tell their story'; they also need 'to tell their story in order to survive. There is, in each survivor, an imperative need to tell and thus come to know one's story'. ${ }^{85}$ In Laub's view, survivors need both time and the presence of two listeners - an external listener who acknowledges the reality of the survivor's lived experience, and an internal listener and agency of the self, who helps comprehend what one has witnessed.

Laub's notion of an external listener and an internal listener resonated in the reasons that respondents gave for wanting to testify before the ECCC. While they wished to confront Duch about specific details regarding their internment or loss of a family member and, through the court process, obtain justice, they also wanted their testimonies to be acts of acknowledgement and remembrance - and, at least in the case of Chum Neou, of familial contrition.

In a similar way to Neth Phally's presentation of his brother's photograph in the courtroom, all but two civil parties wanted to preserve the memory of their deceased relatives in the court record and in the minds of those listening to their testimonies. Referring to his deceased family members, Chum Sirath said:

Who could have told their story, if not me? Those stories have to be told to the court so there will be memory and people will not be forgotten. We know where the mass graves are, but we are unable to attach names to the bones. And if those names are not mentioned in court, we will have no memory. That is why it is my duty to testify. ${ }^{86}$

Martine Lefeuvre described her testimony as 'an act of liberation':

Finally I was going to be able to tell my family's story and especially Ket's story, to give him back his dignity ... to bring him out of the shadows... I took Ket out of his cell where he was rotting and brought him back among us, among the living. ${ }^{87}$

As she entered the courtroom, she realized what a 'great honour' it was to testify, she said. 'I am not a religious person, but I told myself, "Ket is here, his spirit is here"' 88

Antonya Tioulong, whose sister and brother-in-law perished in Tuol Sleng, echoed this sentiment:

It was important for me to confront Duch. It was important to tell him that he hurt us, not only the people he killed, but us. And it was important to testify for my sister, to have her ... being alive again, at least in spirit. ${ }^{89}$

84 See Primo Levi, If This is a Man - The Truce, Penguin Books, London, 1979.

85 Dori Laub, 'An event without a witness: truth, testimony and survival', in Shoshana Felman and Dori Laub, Testimony: Crisis of Witnessing in Literature, Psychoanalysis, and History, Routledge, London, 1992, p. 78.

86 Interview with Chum Sirath, 17 November 2009.

87 Interview with Martine Lefeuvre, above note 77.

88 Ibid.

89 Interview with Antonya Tioulong, 24 November 2009. 


\section{The need to educate the world}

Finally, the majority of the respondents (twelve out of twenty-one) emphasized the educative value that their testimonies might have both for Cambodians and the world at large. "It is important for our children to know about the past so it does not repeat itself, said one respondent, whose brother was executed at Tuol Sleng. Chum Mey, a Tuol Sleng survivor called the court 'a big achievement... that other countries could learn from' and hoped that his testimony had contributed to that effort. ${ }^{90}$

\section{The trial}

During the Duch trial, the ECCC grappled with nearly every aspect of the civil party process - from the purpose and admissibility of civil parties to how best to define the role of their attorneys. As the trial got underway, the court seemed at times like a rudderless ship trying to make its way through uncharted waters. On several occasions, civil party lawyers took to their feet to oppose the prosecution directly or push for their own theory of the case, which bogged down the proceedings. ${ }^{91}$ In the meantime, the defence counsel argued that the civil party lawyers, who were eight strong, were acting as substitute 'prosecutors' and thus threatening 'equality of arms $^{\prime 92}$ - the principle, considered an essential element of a fair trial, that the prosecution and the defence should have procedural equality. ${ }^{93}$ Finally, the Chamber ruled that, while civil parties had the right to support or assist the prosecution, this did not confer on them 'a general right of equal participation with the Co-Prosecutors'. ${ }^{94}$

Throughout Case 001, the judges adopted such a restrictive interpretation of civil party participation that it appeared at times as if they were unwilling to recognize the civil parties as actual parties. Civil parties requested, and were denied, the opportunity to make an opening statement; to submit an opinion as to Duch's request to be released from provisional detention; to respond to the Co-Prosecutor's

90 Interview with Chum Mey, 17 November 2009.

91 Michelle Staggs Kelsall et al., Lessons Learned from the Duch Trial. A Comprehensive Review of the First Case before the Extraordinary Chambers in the Courts of Cambodia, Asian International Justice Initiative's KRT Monitoring Group, December 2009, p. 28, available at: http:/wwwocf.berkeley.edu/ changmin/ documents/Lessons\%20Learned\%20from\%20the\%20Duch\%20Trial_MRSK_FINAL.pdf (last visited 19 December 2011).

92 It quickly became clear that civil party lawyers, many with nominal funding or operating pro bono, had extremely limited resources. This does not excuse but may help to explain their lack of co-ordination and preparation.

93 KRT Trial Monitor, Reports No. 7 (week ending 31 May 2009), No. 9 (week ending 21 June 2009), and No. 21 (week ending 21 September 2009).

94 ECCC, Decision on Civil Party Co-Lawyers' Joint Request for a Ruling on the Standing of Civil Party Lawyers to Make Submissions on Sentencing and Directions Concerning the Questioning of the Accused, Experts and Witnesses Testifying on Character, Case File 001/18-07-2007/ECCC/TC (Trial Chamber), 9 October 2009, para. 25, available at: http:/www.eccc.gov.kh/sites/default/fles/documents/courtdoc/ E72_3_EN.pdf (last visited 6 September 2011). 
opening statement; to make a submission on sentencing; to question the accused on his character; and to pose questions to his character witnesses. ${ }^{95}$

Perhaps the most difficult moment took place midway through the trial, when the defence challenged the admissibility of civil parties who testified based on lack of sufficient evidence of their status as former Tuol Sleng prisoners or as relatives of prisoners who had perished there. ${ }^{96}$ As civil parties struggled to share their stories, the presiding judge, the defence, and the accused picked apart details in their testimonies. Much of the controversy centred on the civil parties' identities or on whether they were detained at Tuol Sleng, as opposed to one of the dozens of other detention centres operated by the Khmer Rouge. During the Khmer Rouge regime, it was not uncommon for someone to adopt a 'revolutionary name', often similar to but slightly different from their given name - a phenomenon that the civil parties tried to explain but that the judges found difficult to understand. The case of Ly Hor was especially problematic. The presiding judge questioned him extensively, resulting in several inconsistencies in his testimony and much confusion. This led a foreign judge to criticize Ly Hor's preparation and admonish his lawyer, who admitted that he had relied on a translation from an intermediary organization and failed to communicate with Ly Hor directly. At the end of Ly Hor's testimony, Duch accused him of lying about his identity, claiming that the real Ly Hor had been killed. ${ }^{97}$

It soon became clear to everyone that the civil parties needed better preparation. Several civil party lawyers had not expected their clients to be examined and cross-examined like witnesses, and thus were unprepared for the scrutiny. Further, the detailed questions necessary to vet the parties' identities ignored the potential trauma of having one's identity challenged, the likelihood of a faulty memory after thirty years, and the sheer difficulty of explaining clearly what had occurred in such a nightmarish situation. Fortunately, the next week of civil party testimony was much improved - at least from a procedural perspective - as civil party lawyers presented all identity documents prior to each testimony, and most testifiers simply read a statement from the stand.

\section{Preparing to testify}

Because testifying in a criminal court often means confronting the alleged perpetrator and reliving the crime, there is always the danger that disturbing memories and sensations will overwhelm a civil party or witness. Psychologists call this phenomenon psychophysiologic reactivity: when describing past traumatic episodes survivors often react physically as well as psychologically. Physical reactions may include sweating, trembling, and heart palpitations. ${ }^{98}$

95 See M. S. Kelsall et al., above note 91, p. 32.

96 Ibid., pp. 29-30.

97 ECCC, Transcript of Trial Proceedings - Kaing Guek Eav 'Duch', Case File No. 001/18-07-2007-ECCCC/ TC, 6 July 2009, Trial Day 39, pp. 82-87, available at: http//www.eccc.gov.kh/en/documents/court/ transcript-proceedings-\%E2\%80\%9Cduch\%E2\%80\%9D-trial-trial-day-39 (last visited 6 September 2011).

98 See Robert J. McNally, Remembering Trauma, Harvard University Press, Cambridge, MA, 2003, p. 106. 
If we were ever prompted to design a system for exacerbating pre-existing emotional and psychological suffering, ${ }^{99}$ we could not do better than a court of law. Indeed, the mental health needs of victims of war crimes, as the psychiatrist Judith Herman writes, are often diametrically opposed to the requirements of legal proceedings. Victims need to establish a sense of power and control over their lives; the court requires them to submit to a complex set of rules and procedures which they may not understand, and over which they have no control. Victims need an opportunity to tell their stories in their own way, in a setting of their choice; the court requires them (at least in common law trials) to respond to a set of 'yes' or 'no' questions that break down any personal attempt to construct a coherent and meaningful narrative. ${ }^{100}$

Yet, as difficult as testifying might be, it does not mean that civil parties or witnesses necessarily become traumatized by their court experience or consider it a negative experience. As a recent survey of the extant empirical literature suggests, there is little evidence that truth-telling mechanisms, including war crimes tribunals in post-war settings, either 'dramatically harm[s] individuals... [or] ease their emotional and psychological suffering'. ${ }^{101}$ The effects may be quite individual and varied. We simply do not know.

What we do know is that many victims and witnesses, when asked to testify about war crimes, have expressed trepidation about their own safety and the safety of their families, as well as about their own ability to withstand the rigours of recalling painful memories in a public setting. ${ }^{102}$ Such concerns, however, are not uniform and often vary depending on the cultural, political, and security dynamics of the post-conflict setting. The civil parties whom we interviewed in Cambodia, for example, expressed few serious concerns about their physical safety, largely because they felt that Cambodia was finally at peace. Only one respondent was concerned that Duch's family members might seek revenge.

That said, many were concerned about how they would perform in the courtroom, especially when relating traumatic events and feelings, and, ultimately, how the judges and audience would perceive their testimonies. Respondents described a range of physical and emotional symptoms, including a perceived rise in blood pressure, sweaty palms and feet, trembling hands, and alternate feelings of terror and lightness immediately before entering the courtroom. 'I was so anxious', Ouk Neary said. 'I was shaking and I never shake. My hands were trembling, so

99 Multiple studies suggest that the psychological effects of traumatic exposure during the Khmer Rouge periods have been profound, including a high prevalence of post-traumatic stress disorder (PTSD), somatic symptoms, and disability among the survivors. See Jeffrey Sonis, et al., 'Probable posttraumatic stress disorder and disability in Cambodia: associations with perceived justice, desire for revenge, and attitudes towards the Khmer Rouge trials', in Journal of the American Medical Association, Vol. 302, No. 5, 2009 , p. 527.

100 Judith Lewis Herman, 'Justice from the victims' perspective', in Violence Against Women, Vol. 11, No. 5, 2005, p. 574.

101 David Mendeloff, 'Trauma and vengeance: assessing the psychological and emotional effects of postconflict justice', in Human Rights Quarterly, Vol. 31, No. 3, 2009, p. 593.

102 See E. Stover, above note 32, pp. 74-75. 
I knitted my fingers together and told myself, "Okay, your hands don't move anymore"'.103

Ou Savrith admitted that, although he was accustomed to speaking at large business gatherings, he was besieged with 'performance anxiety' before he stepped into the courtroom:

I kept thinking: 'Will others be interested in what I say? In what I think? What I have suffered?' You know, we, Cambodians are not comfortable expressing ourselves. We keep our feelings to ourselves.... I don't want to bother or frustrate people because I believe suffering is individual. So I was afraid that I would not know what to say in the face of millions of deaths, not only my brother's death, and that what I said would not be interesting or important to people. Testifying before a court needs dignity; you need to be clear and understandable, and I was scared I might just collapse. ${ }^{104}$

Martine Lefeuvre describes how she coped with her courtroom appearance:

I knew as the first civil party to testify that week, I was going through a 'test of fire'. Really, my heart was about to explode. When I got to the witness stand, the first thing I did was bow to the public as Ket was my tie to Cambodia, and this was important for me. Then I paid my respect to the court which was finally there for us. I told myself, 'I'll occupy this place. It is small, maybe a square metre, but it is going to be my place. I will get comfortable. This is my place'... My [lawyer?] told me to speak slowly. And I am grateful not to have been interrupted. This was very, very important because Ket's story had to be told without interruption. ${ }^{105}$

\section{Confronting Duch}

Once in the courtroom civil parties were seated in the witness box facing the judges, with their backs to the public gallery. To their left were the civil party lawyers and national and international prosecutors; the two defence lawyers, flanked by assistants, were to their right, as was the accused, who sat no more than two metres away from the civil parties. By turning slightly to their right, civil parties could look directly at the accused.

'I knew if I had ever encountered Duch, we would have probably fought', one respondent said later. 'But my lawyer and the NGOs told me to hold my temper, so that is what I did'. ${ }^{106}$ Another respondent told us: 'I grew angry when I saw the accused. He knew my cousin. He accompanied him to the airport when he left the country to study abroad'. 107 When the respondent's cousin returned to Cambodia, Duch allegedly arrested him and later ordered his execution. 
But not all civil parties were as restrained in the courtroom as those two. For example, Chum Mey, a survivor of S-21, lashed out at Duch, just after describing being subjected to electric shocks and repeated beatings. 'So I would like to tell this to Duch', Chum Mey said as he turned toward the accused, '... Duch did not beat me personally, directly, otherwise he would not have the day to see the sunlight. I just would like to be frank.' 108 In a prompt response, the presiding judge rebuffed the Tuol Sleng survivor for being abusive and insulting in a courtroom setting. ${ }^{109}$

Several respondents described 'locking eyes' with Duch before or during their testimonies. Some said that they did it as a means of showing their resolve or expressing their unwillingness to forgive him. Others, like Robert Hamill, said they felt that the accused was trying to intimidate them:

I looked across the courtroom and Duch was staring at me. I stared back and we made contact for a good ten seconds. I didn't show any expression, and neither did he. Finally, he broke away. Now when I look back on that moment, I think how incredibly rude it was because in any culture but especially [Cambodian] culture you don't look people in the eye that way. And it just said so much about how this guy, who had done these terrible atrocities to my brother and all those people, was still prepared to look me in the eye and stand his ground. It made me wonder just how remorseful he really was. ${ }^{110}$

'Duch is like that', Ouk Neary said, referring to his manner of confronting his accusers in the courtroom. 'He is always trying to see what is true in what you say and when you have made a mistake.' Of her days in court prior to testifying, Neary said:

I observed Duch [but] I didn't want him to look at me. I didn't want him to touch me with his look.... It is not that I didn't have any courage to face him. It was that I was feeling respect for my Dad as he would not have liked this guy to have touched me with his eyes. ${ }^{111}$

In describing their testimonies, the respondents became most animated when recalling the moments when Duch apologized and asked forgiveness for his crimes. The former prison commander's first admission that he was responsible for atrocities at S-21 took place in the afternoon of 31 March 2009, the second day of the proceedings. 'I would like to... emphasize that I am responsible for the crimes committed at S-21, especially the tortures and execution of the people there', he said. $\mathrm{He}$ also asked his victims to 'leave an open window for me to seek forgiveness'. 112

Addressing the court, he said that he had feared for his own life and did not dare to think of challenging his superiors: it was the life and death situation of me,

108 See Trial Day 36, above note 81, p. 12.

109 Ibid., pp. 12-14.

110 Interview with Robert Hamill, conducted via telephone, 25 November 2009.

111 Interview with Ouk Neary, above note 103.

112 See ECCC, Transcript of Trial Proceedings - Kaing Guek Eav 'Duch', Case File No. 001/18-07-2007ECCCC/TC, 31 March 2009, Trial Day 2, pp. 67-68, available at: http:/www.ecc.gov.kh/en/documents/ court/transcript-procedings-\%E2\%80\%9Cduch\%E2\%80\%9D-trial-trial-day-2 (last visited 7 July 2011 ). 
myself, and my family as a whole', he said. 'As the person who was in charge of S-21, I never attempt to find other alternatives other than obeying the orders, although I know that obeying the order meant that the lives of numerous people would be perished.' He had an affinity with survivors of the Khmer Rouge, he said, and claimed that he felt remorse and shame in the eyes of people who are victims and those who lost loved ones during the regime, and including my families who lost members of the family also'. ${ }^{113}$

A few civil parties suggested that Duch's apparent co-operation and truthtelling would offer some of the historical clarification that many Cambodians were seeking, but none felt that his apology was sincere. 'Duch's apology just comes from his lips, not from his heart', said Nam Mon. 'It's a total masquerade', Ouk Neary added.

You can see when he refers to himself as the chief of S-21, he is proud of it as if he is the S-21 employee of the month. He may say he is responsible, but never says for what. He never says, 'I have killed 17,000 persons'.

When asked if she accepted his 'apology' at the end of her testimony, she bristled: 'In his way, he said I want to bow down in front of you. He said it but he didn't do it'. According to Ouk Neary, whose father had perished at Tuol Sleng, it was as if he were saying, "You are like all those orphans whose parents died, nothing special, you are not the only one." Well, I understood the double-meaning of his sentences'. ${ }^{114}$

Before testifying, one respondent asked his three children if he should accept Duch's apology; they all said 'no'. On the witness stand, he read a statement from his niece, who was four years old when her father perished at Tuol Sleng. She, too, refused to forgive Duch and explained why:

to grant forgiveness comes down to saying that finally no serious crime was committed. To grant forgiveness boils down to admitting that the atrocities committed do not touch us deeply. To grant forgiveness would mean to feel pity, but how can anyone feel pity for a man who has taken away so many lives? Did he have any pity for the women, the children, and the men he caused to be assassinated? ${ }^{115}$

Before testifying, Hav Sophea had wanted Duch to apologize for the death of her father. But she found what he said in the courtroom deeply disappointing:

When I saw the accused I felt quite tense, but after we both spoke and he accepted responsibility for the death of my father, it helped me release my tension. But then, in the end, he said he wasn't sure if I was my father's daughter. That really upset me. Why did he have to say that? ${ }^{\text {16 }}$

113 Ibid., p. 69.

114 Interview with Ouk Neary, above note 103

115 See ECCC, Transcript of Trial Proceedings - Kaing Guek Eav 'Duch', Case File No. 001/18-07-2007ECCCC/TC, 20 August 2009, Trial Day 62, p. 63, available at: http:/www.ecc.gov.kh/en/documents/ court/transcript-proceedings- $\% \mathrm{E} 2 \% 80 \% 9 \mathrm{Cduch} \% \mathrm{E} 2 \% 80 \% 9 \mathrm{D}$-trial-trial-day- 62 (last visited 7 July 2011 ).

116 Interview with Hav Sophea, 13 November 2009. 
In a similar vein, Antonya Tioulong found Duch's questioning of whether or not her sister was ever detained at S-21 very upsetting:

What I really wanted to know was what Duch did to my sister. At first he said he didn't know she was at S-21. Then, a few moments later, he said he heard her voice. So which one is it? He knew? Or he didn't know? This made me really angry. I controlled myself because I didn't want to cause an incident in the courtroom. But I had a lot of anger. And I told him that I would never forgive him. ${ }^{117}$

Several civil parties characterized Duch's admissions of guilt and responsibility as Janus-faced acts of contrition aimed at gaining the sympathy of the judges, especially the foreign ones. Chum Sirath explained what he saw as Duch's psychological and strategic objectives:

When Duch speaks of forgiveness, he repeatedly says he is responsible for all those crimes as only one member of the Communist Party of Kampuchea $[\mathrm{CPK}]$. It is his way of always diverting responsibility. It is as if he is saying: 'I am one of a million members of the CPK therefore I bear a millionth of the responsibility'. When he addresses individuals who he feels inferior to, he flatters them. But when it comes to the civil parties he considers beneath him, he crushes them. But he does this in a very subtle way. Here and there he accepts certain things the civil parties say as the truth, while still managing to sow doubt about their veracity. ${ }^{118}$

\section{The experience of testifying}

Human rights advocates have argued that victims who speak publicly about their ordeals in criminal trials or before truth commissions often experience catharsis, which, in turn, can lead to healing and closure. ${ }^{119}$ But psychoanalysts and psychologists take a more critical view of the idea of a quick, cathartic cure as a result of testifying. ${ }^{120}$ For example, one respondent told us that he felt elated after his testimony but it took only a matter of hours for the feeling to pass:

After the testimony, when the microphone was switched off, I felt happy. It was like being relieved of a big weight. I was feeling light. My head was free. I was happy. During those two hours, I thought that [my suffering] was over. But, as I found out later that wasn't the case at all. Still I will remember those two hours for the rest of my life. ${ }^{121}$

117 Interview with Antonya Tioulong, above note 89.

118 Interview with Chum Sirath, above note 86.

119 See, e.g., Laurel E. Fletcher and Harvey M. Weinstein, 'Violence and social repair: rethinking the contribution of justice to reconciliation', in Human Rights Quarterly, Vol. 24 , No. 3, 2002, pp. $592-593$.

120 Ibid., pp. 593-594.

121 Interview, 24 November 2009. 
The majority (seventeen out of twenty-one) of the civil parties whom we interviewed characterized their court experiences as largely positive, the remaining four saying that it was a mixed experience. Most said they left the courtroom in a highly charged emotional state. But, beyond that, the respondents described a variety of reactions and shifting emotions during and immediately after their courtroom experience. These accounts affirm earlier studies of victim-witnesses who have testified in war crimes trials, ${ }^{122}$ and suggest that the act of giving testimony either as a victim-witness or as a civil party is a multifaceted experience, fraught with unexpected challenges and emotional swings, rather than one that is wholly cathartic.

Civil parties described a range of feelings as they left the courtroom. Some said that they felt 'disappointed' for having failed to recount important details or not having enough time to tell their story. Bou Meng, an S-21 survivor said:

Testifying helped me release some anger. But I failed to tell the court how I had lost my career as a painter because of my treatment at S-21. I wanted to tell the court that I am now disabled, that my sight and hearing have deteriorated greatly. But the court didn't ask me what the torture did to my body. ${ }^{123}$

Neth Phally put it this way:

When I left the courtroom my feelings had been eased, and I left hopeful that the court would provide justice for my brother. But I also felt dissatisfied that I was unable to tell my whole story. One hour is not enough time. ${ }^{124}$

Hav Sophea said that, as she left the courtroom, she felt something was missing:

I wasn't angry or disappointed with the court, I just felt I missed the opportunity to tell my whole story. I had wanted to tell the accused: 'If I was not my father's daughter, why would I have come? I would not have wasted my time doing this'. ${ }^{125}$

Four of the twenty-one civil parties whom we interviewed found testifying very difficult, largely because it meant recalling painful events. Chum Neou, who lost both her husband and child during the Khmer Rouge period, characterized her time in the courtroom as bittersweet; at one point she became so distraught a TPO social worker was asked to sit with her in the witness stand. She said:

It was important to tell my story, to tell about my life after hiding it for thirty years [but] it was very difficult, too. How could I explain my tremendous sadness and suffering to the court? My first hearing took place, and then I had to wait three days before I could continue. It was difficult. During those three 
days, I tried to keep all the stories straight in my head so I could recount them accurately for the court. ${ }^{26}$

Chin Met said the court treated her respectfully, but that the process of recalling a past she had buried was gut-wrenching:

The whole story I have tried to forget just came back to me. The lawyers and the non-governmental organizations keep asking me the same questions again and again, and it always brings back the sadness.... It is like a healed wound that is being picked at by a stick. When I walked out of the court, I did not feel I got any benefit from it. Only the court got some benefits. ${ }^{127}$

Several civil parties derived great satisfaction from testifying. The most demonstrative was Chum Mey, President of the Victims Association of Democratic Kampuchea (Ksem Ksan), an organization comprised in part of victims of the Khmer Rouge. Several days a week, Chum Mey works as a guide at Tuol Sleng, where he leads tour groups around the grounds of the former prison. He said,

Before entering the courtroom I felt tense in my chest. But after I talked to the judges and related my story, I felt like all of this tenseness was released. Like right now when I tell my story to visitors to Tuol Sleng, I can control myself. I don't cry like I used to. Before I testified, I kept thinking I should probably see a psychiatrist, but after I testified I realized my feelings had become normal. ${ }^{128}$

A victim's response to the stress of testifying can, of course, fall anywhere on a continuum from the traumatic to the pleasurable, but how the victim internalizes that stress will largely depend on his or her perception of the trial's outcome and the extent to which it validated his or her participation in it. ${ }^{129}$

\section{A sense of justice}

Since the mid-1970s, social psychologists have surveyed people around the world who have participated in judicial proceedings and various forms of arbitration to understand what it is about such processes that leads participants to consider them fair or unfair, and ultimately to accept or reject the outcome. Almost universally, these studies have concluded that the manner in which a trial is conducted and the extent to which participants have a 'voice' in the proceedings are major influences - though not the only ones - on satisfaction that justice was done. ${ }^{130}$

126 Interview with Chum Neou, 12 November 2009.

127 Interview with Chin Met, above note 67.

128 Interview with Chum Mey, above note 90.

129 R. J. McNally, above note 98, pp. 98-99.

130 See, e.g., John W. Thibaut and Laurens Walker, Procedural Justice: A Psychological Analysis, Lawrence Erlbaum Associates, Inc., Hillsdale, NJ, 1975; Edgar Allan Lind and Tom R. Tyler, The Social Psychology of Procedural Justice, Plenum, New York, 1988; Edgar Allan Lind, Ruth Kanfer, and P. Christopher Earley, 'Voice, control, and procedural justice', in Journal of Personality and Social Psychology, Vol. 59, No. 5, 1990, pp. 952-959; Robert J. Maccoun, 'Voice, control, and belonging: the double-edged sword of procedural fairness', in Annual Review of Law and Social Science, Vol. 1, 2005, pp. 171-201; David De 
According to these studies, individuals define a 'fair process' as one that is based largely on three criteria: benevolence - the degree to which they perceive that the authorities care about them and their experiences; neutrality - the extent to which they have been able to talk about their experiences in a neutral and unbiased forum; and respect - the extent to which they have been treated in a professional and dignified manner. "Judgments about "how hard" the authorities tried to be fair emerged as the key overall factor in assessing procedural justice', writes the social psychologist Tom Tyler. ${ }^{131}$ In effect, those involved in judicial processes are looking for signs that they can trust the authorities. ${ }^{132}$ For this reason, showing the utmost respect to witnesses and civil parties in the courtroom is a key component for building trust in a court's authority and legitimacy.

The civil parties whom we interviewed tended to express the most dissatisfaction with the ECCC when they perceived that either the judges or defence attorneys were failing to respect their interests, were showing favouritism to the accused, or were adopting measures that restricted their role and the role of their lawyers in the courtroom. This was particularly evident near the end of the trial when a group of twenty-eight civil parties, including many of those whom we interviewed, boycotted the proceedings for a week. ${ }^{133}$ The incident arose when the Chamber determined that the civil party lawyers would not be permitted to question the accused or witnesses called by the defence to testify about Duch's character, nor make submissions on sentencing. What particularly irked the civil parties was the Chamber's determination that their role as civil party participants did not confer on them 'a general right of equal participation' with the prosecution, nor 'transfer them into additional prosecutors.'. ${ }^{134}$

\section{A sense of fairness}

Despite these setbacks, only one of the respondents felt that the trial proceedings were unfair, and even his criticisms focused more on

Cremer and Constantine Sedlikides, 'Self-uncertainty and responsiveness to procedural justice', in Journal of Experimental Social Psychology, Vol. 41, 2005, pp. 157-173.

131 Tom R. Tyler, "What is procedural justice? Criteria used by citizens to assess the fairness of legal procedures', in Law and Society Review, Vol. 22, No. 1, 1988, p. 129.

132 See Bernard Barber, The Logic and Limits of Trust, Rutgers University Press, New Brunswick, NJ, 1983; and Tom R. Tyler, 'When does procedural justice matter in organizational settings?', in Roy J. Lewicki, Blair H. Sheppard, and Max H. Bazerman (eds), Research on Negotiation in Organizations, Vol. 1, JAI Press, Greenwich, CT, Vol. 1, pp. 7-23.

133 See 'Letter of civil parties in Case 001 to the President of the Trial Chamber', available at: htip:/www.ecc. gov.kh/sites/default/files/documents/courtdoc/E166.1_FR.pdf (last visited 7 September 2011). The letter was in response to the Trial Chamber's oral decisions on civil party lawyers to make submissions on sentencing and questioning of the accused, experts, and witnesses testifying on character: see ECCC, Transcript of Trial Proceedings - Kaing Guek Eav 'Duch', Case File No. 001/18-07-2007-ECCCC/TC, 27 August 2009, Trial Day 66, pp. 42 and 74FN, available at: http:/www.ecc.gov.kh/sites/defaulv/hles/ documents/courtdoc/E1_70.1_TR001_20090827_Final_EN_Pub.pdf (last visited 7 September 2011). See also KRT Trial Monitor, Report No. 20 (week ending 4 September 2009), p. 2.

134 Decision on Civil Party Co-Lawyers' Joint Request, above note 94, para 25. 
what he perceived as the incompetence of the prosecutors than any bias. 'Still', he said,

it was necessary to have such a court, to show the leaders that there is no impunity ... and for the victims to impart a feeling that we have done our duty toward our missing loved ones. And, for the country, for the people, so they will see that impunity is not there all the time. ${ }^{135}$

Most civil parties whom we interviewed (fifteen out of twenty-one) said that the trial had been fair. 'I felt respected by the court', Neth Phally said, ${ }^{136}$ while another respondent, who had been grilled about his identity by the judges and defence, characterized the proceedings as 'very fair' and said 'full rights' were provided to everyone. ${ }^{137}$ Robert Hamill, whose brother died at S-21 agreed. He added that it was his 'understanding that there was a negative response from one or two judges to the idea of hearing civil parties. Because of that, I wanted ... to show that I appreciated the opportunity that they allowed us to participate.' ${ }^{138}$ Another respondent, echoing the sentiments of others, felt that the international presence in the court helped to keep the proceedings impartial. ${ }^{139}$

Our interviews suggest that, overall, the civil parties found the trial process to be fair, although they did express dissatisfaction with certain decisions and procedures imposed on their legal counsel by the court. First and foremost among these was the perceived inequality of means and resources provided to the defence and to the civil party lawyers. Antonya Tioulong said,

I am very grateful to have been selected to testify in this trial. But I do believe there has been a great imbalance between the defence and civil parties. During the closing arguments, for example, the defence received seven hours to present [its] case while the civil parties only received five and a half hours. ${ }^{140}$

\section{Reparations}

Reparations for large-scale violations of human rights may be material or symbolic, or a combination of the two. ${ }^{141}$ Material reparations stem from the compensatory theory of justice: wrongdoers should not only pay victims for their injuries and losses, but the compensation should be proportional to the injury or loss inflicted. ${ }^{142}$ Symbolic reparations emphasize the significance of official acknowledgement of wrongdoing and the need to pay respect to survivors or those who have died. Reparations can be one-off financial payment to individual victims, or collective processes such as public memorials, days of remembrance, parks, renaming streets

135 Personal interview conducted by authors on 24 November 2009.

136 Interview with Neth Phally, above note 2.

137 Interview, 22 November 2009.

138 Interview with Robert Hamill, above note 110 .

139 Interview, 17 November 2009.

140 Interview with Antonya Tioulong, above note 89.

141 See Pablo de Greiff (ed.), The Handbook on Reparations, Oxford University Press, New York, 2006.

142 See, e.g., John Rawls, A Theory of Justice, Harvard University Press, Cambridge, MA, 1971. 
or schools, preserving repressive sites and burial grounds as museums, and other ways of creating public memory. They can include state educational reform, the rewriting of historical accounts, education in human rights and tolerance, and public apologies from governmental authorities. ${ }^{143}$

The principle of reparations is well recognized in Cambodian law. ${ }^{144}$ Indeed, most Cambodians favour some form of reparations for victims of the Khmer Rouge. In a 2008 survey of 1,000 Cambodians, $88 \%$ said that reparations should be provided to victims, while $68 \%$ said that they should be provided to the community as a whole. Over half (53\%) said that reparations should be in a form that affects the daily lives of Cambodians, including social services (20\%), infrastructure development (15\%), economic development programmes (12\%), housing and land (5\%), and provision of livestock, food, and agricultural tools $(1 \%){ }^{145}$

The right to claim reparations did not feature in the ECCC's founding statute, but it is reflected in the Internal Rules, which provide that the Chamber may award collective and moral-but not individual financial-reparations to civil parties, which 'shall be awarded against, and be borne by convicted persons'. ${ }^{146}$ The Internal Rules further clarify that such reparations may include ordering a convicted person 'to publish the judgment in any appropriate news or other media', to 'fund any non-profit activity or service that is intended for the benefit of victims', or 'other appropriate and comparable forms of reparation'. 147

Civil party lawyers in the Duch case recommended that the court award their clients and the Cambodian people 'a range of reparations that roughly fall under the headings of outreach and dissemination of information and apology, medical care including psychological and physical care, educational programs, and memorialization of victims. ${ }^{148}$ Our interviews with civil parties revealed a wide range of opinions regarding reparations. Several respondents, while recognizing the symbolic importance of reparations, questioned whether compensation of any kind could truly contribute to individual and social repair after so many years. "How do you put a number on suffering?', asked one respondent. 'The fact of having testified is already moral reparation. Getting answers, knowing what happened.... The

143 See Naomi Roht-Arriaza, 'Reparations in the aftermath of repression and mass violence', in Eric Stover and Harvey M. Weinstein (eds), My Neighbor, My Enemy: Justice and Community in the Aftermath of Mass Atrocity, Cambridge University Press, Cambridge, 2004, pp. 121-139.

144 Article 14 of the Code of Criminal Procedure for the Kingdom of Cambodia provides that 'An injury can be compensated by paying damages, by giving back to the victim the property that has been lost or by restoring damaged or destroyed property to its original state'.

145 Phuong Pham, Patrick Vinck, Mychelle Balthazard, Sokhom Hean, and Eric Stover, So We Will Never Forget: A Population-based Survey on Attitudes about Social Reconstruction and the Extraordinary Chambers in the Courts of Cambodia, Human Rights Center, University of California, Berkeley, CA, January 2009, pp. 43-44.

146 ECCC, Internal Rules, above note 4, Rule 23(11).

147 Ibid, Rule 23 (12).

148 See ECCC, Case File 001/18-07-2007/ECCC/TC, Civil Parties Co-Lawyers' Joint Submission on Reparations (Trial Chamber) 14 September 2009, para. 11, available at: http://www.eccc.gov.kh/en/ documents/court/civil-parties-co-lawyers-joint-submission-reparations (last visited 7 July 2011). 
concept of reparation, it seems to me, is out of place. Reparation? How can we be repaired? This is not possible'. ${ }^{149}$

Others believed that they should receive individual material reparations, especially in the form of medical and psychosocial care, or a fund to enable them to hold a Buddhist ceremony to honour the memory of those loved ones who had perished at S-21. Civil parties spoke of reparations in the same terms as they did their court testimonies: namely, as a form of official recognition and acknowledgement of their suffering, and that of the Cambodian people.

\section{Overall experience}

In a Yugoslav victim-witness study, the vast majority of respondents said that they felt it was their 'moral duty to bear witness on behalf of their deceased family members and neighbors', and that they regarded their time on the witness stand as an opportunity to discharge that obligation, as well as an 'opportunity to confront their tormentors'. ${ }^{150}$ In many cases, if these overarching needs were realized and witnesses felt that they had been treated respectfully, they were generally willing to overlook trial inequities or difficult moments (a withering cross-examination, for example) that arose during their interaction with the court.

When reflecting on their overall experience the civil parties whom we interviewed provided four general observations. First, the vast majority of respondents said testifying had been the most important part of their overall experience of being a civil party. Hav Sophea, echoing the sentiments of many of her counterparts, said:

The most important moment in the whole process was being able to testify, to be able to be there in the courtroom and to tell my story. It was a privilege that I was allowed to testify and that I was able to express the feelings of other victims of the Khmer Rouge time. ${ }^{151}$

Second, many said that their experience as a civil party had been transformative for them and, in some cases, for their families. Robert Hamill spoke of how his testimony had helped his sister and the family of a friend who had perished with Hamill's brother at Tuol Sleng cope with their losses. ${ }^{152}$ Ouk Neary also found the experience transformative: 'I would never have imagined I would be able to speak. I was very surprised by what I did ... I grew up and became mature because of the whole process. Now I have my eyes wide open'. ${ }^{153}$

After testifying, Neary went alone to Tuol Sleng before her return trip to France. 'I went to my father's cell and knelt on one knee and I talked to my Dad for five minutes', she recalled. 'Finally, I rose and said, "Okay, Dad, let's go. You can't stay here any more, and neither can I" '. Neary said that the visit was to set both her 
and her father free. 'In my mind I had been in S-21 for more than thirty years and I wanted to get out', she said. 'Because I didn't know the truth [for all those years], I was in the cell with my Dad. And now it was time to be free'. ${ }^{154}$ Ouk Neary's mother, Martine Lefeuvre, summed up her own experience this way: 'It [was] a beginning of reparation, something turned. I felt that people understood our family's suffering.... And now I don't want our family to return to its solitude, its nonexistence like it was since $1977^{\prime}{ }^{155}$

Third, many civil parties noted with approval how the overall trial experience had introduced them to others who had suffered. Martine Lefeuvre said:

The group of civil parties were able to talk to one another. [We] had an affinity, even without knowing one other. We listened to the stories of others because some of us have the same lawyers. For others we also heard their stories in the group, and it created solidarity, kindness, empathy - that is one of the things I really liked about the process. ${ }^{156}$

Chum Sirath put it this way:

Meeting other civil parties creates friendships. For example, for me, personally, I couldn't talk about my suffering... but meeting with other civil parties it allows me to talk about it. ... We've built friendships. And now we take care of each other.... There is a kind of self-help between victims... and perhaps it helps to keep alive the memory of our family and ... help to prevent the return of such crimes. ${ }^{157}$

As the Duch trial progressed it became evident that many of the civil parties had formed strong, supportive bonds. In September 2009, weeks after the civil party boycott, a group of civil parties from both Cases 001 and 002 decided to form the Victims Association of Democratic Kampuchea (or Ksem Ksan Association), one of the first victims' associations in Cambodia. ${ }^{158}$

Fourth and finally, most of the civil parties whom we interviewed felt that their motivation to bear witness on behalf of their deceased family members had been realized through the trial process. Some said that the actual experience of testifying far exceeded their initial expectations and, if given the chance, they would encourage others to testify. A few said that they had wanted Duch to admit to having ordered the execution of a family member, and when he failed to do so they felt that their mission had not been fulfilled. Such misgivings, however, did not undermine their general feelings of satisfaction.

155 Interview with Martine Lefeuvre, above note 77.

156 Ibid.

157 Interview with Chum Sirath, above note 86.

158 More information about the Ksem Ksan Association can be found at: http:/ksemksan.org/index.php? nav $=$ home \&lang=en (last visited 7 July 2011). 


\section{The verdict}

On the morning of 26 July 2010, hundreds of Cambodians travelled to the court to hear the ECCC's verdict. ${ }^{159}$ After the judges filed into the chambers and took their seats, the Court president and presiding judge, Nil Nonn, pronounced Duch 'individually criminally responsible' for crimes against humanity and grave breaches of the Geneva Conventions of $1949 .{ }^{160}$ He then addressed the admissibility of the civil party applicants and read out the names of sixty-six of the ninety who had applied. Twenty-four had been rejected, including some who had testified, 'because the Chamber [was] not satisfied ... that the ... Civil Parties were victims of crimes committed by Kaing Guek Eav at S-21 or S-24. ${ }^{161}$ Civil Parties failed to establish that their lost relatives were victims of crimes for which Kaing Guek Eav was convicted ${ }^{162}$ or failed to prove a close kinship or bond of affection or dependency on victims of S-21 or S-24. ${ }^{163}$ The president went on to say that reparations would be limited to the inclusion in the judgment of the names of the sixty-six accepted civil parties and the name of any family member who might have been harmed at S-21, as well as a compilation and publication of all statements of apology made by the accused, which would be posted on the ECCC website. ${ }^{164}$ Other requests such as individual monetary awards, a national commemoration day, construction of pagodas, preservation of archives, and access to medical care and education were considered outside the competence of the Court or lacking specificity. ${ }^{165}$

Next, the presiding judge announced that the accused would be sentenced to thirty-five years' imprisonment, which would be reduced to nineteen years, owing to time already served and to compensate for a period of illegal detention by a Cambodian military court. ${ }^{166}$ Immediately after the verdict, the victims' association issued a prepared statement in which it spoke approvingly of Duch's conviction but criticized the relatively light sentence, the Court's rejection of twenty-four civil parties, and the lack of tangible reparations. Three weeks after the verdict, the CoProsecutors filed a notice of appeal requesting the Supreme Court Chamber... increase the term of imprisonment against Duch'. ${ }^{167}$ Duch appealed his conviction ${ }^{168}$

159 One of the authors - Mychelle Balthazard - attended the verdict.

160 See Case 001, Judgment, above note 3, para. 568.

161 Ibid., para. 647.

162 Ibid., para. 648 .

163 Ibid., para. 649 .

164 Ibid., paras. $667-675,683$.

165 Ibid., paras. $652-658$.

$166 \mathrm{Ibid}$., paras. 679-681. The prosecution had asked for a forty-year sentence after taking into consideration mitigating factors and Duch's earlier illegal detention.

167 See Statement of the Co-Prosecutors, Extraordinary Chambers in the Courts of Cambodia, 16 August 2010, available at: http:/www.eccc.gov.kh/en/articles/statement-co-prosecutors (last visited 7 July 2011).

168 See ECCC, Notice of Appeal, by the Co-Lawyers for Kaing Guek Eav Alias Duch against the Trial Chamber Judgment of 26 July 2010, 24 August 2010, 001/18-07-2007-ECCC/TC, available at: http:// www.ecc.gov.kh/en/document/court/notice-appeal-co-lawyers-kaing-guek-eav-alias-duch-against-trialchamber-judgement-26 (last visited 7 September 2011). See also Associated Press, 'Former Khmer Rouge chief appeals against conviction', 15 August 2010. 
and many civil parties appealed their rejection. ${ }^{169}$ The Supreme Court will pronounce its judgment on this issue in February 2012.170

Over the ensuing days, local and international media ran numerous stories focusing on the civil parties distress. ${ }^{171}$ Some journalists even portrayed the sentence as a threat to the development of the rule of law in Cambodia. The ECCC had been seen as playing an important role in helping rebuild trust in a Cambodian legal system that had been decimated thirty years earlier, but, at least in the eyes of these journalists and commentators, that role was now compromised by the lightness of the sentence compared to the enormity of the crimes. ${ }^{172}$

In the meantime, the TPO reported that it had received distressed phone calls from several civil parties whose status was denied by the Trial Chamber. Some callers expressed shame and guilt for having failed their deceased loved ones. 'I had promised to my ancestors to seek justice for my relatives who died at S-21', said one caller, 'but I cannot ... I am not good enough'. Another said: 'I don't want to go out of my house because I do not want to tell my neighbours that I was rejected as a civil party. It is for me a major loss of face!'173 After a meeting of civil parties immediately following the verdict, the TPO reported that many participants 'expressed strong feelings of anger, sadness, disappointment, injustice, and helplessness' ${ }^{174}$ at both the sentence and the Court's rejection of twenty-four civil parties. ${ }^{175}$

169 See ECCC, Group 1 - Civil parties' co-lawyers immediate appeal of civil party status determinations from the final judgment, 24 August 2010,001/18-07-2007-ECCC/SC, available at: http:/www.ecc.gov.kh/sites/ default/fles/documents/courtdoc/E188_10_EN_CPG1.pdf; ECCC, Co-lawyers for civil parties group 2: Appeal against rejection of civil party applicants in the judgment, 22 October 2010, 001/18-07-2007ECCC/SC, available at: http:/www.ecc.gov.kh/sites/default/files/documents/courtdoc/F11_EN.pdf (last visited 7 September 2011); ECCC, Appeal of the Co-Lawyers for the Group 3 Civil Parties against the Judgment of 26 July 2010, 5 October 2010, 001/18-07-2007-ECCC/OCIJ, available at: http://www.ecc.gov. $\mathrm{kh} / \mathrm{sites} / \mathrm{default} / \mathrm{fl}$ es/documents/courtdoc/Fg_EN.pdf (last visited 7 September 2011). The appeal hearings against the Trial Chamber's judgment were held on 28-30 March 2011. See ECCC, Transcripts of Appeal Proceedings - Kaing Guek Eav 'Duch', 001/18-07-2007-ECCC/SC, available at: http:/www.ecc. gov.kh/en/indicted-person/66/transcript. At the time of writing, the Supreme Court Chamber's decisions on the appeals were still pending.

170 See ECCC, Case File No. 001/18-07-2007-ECCC/SC, Order Scheduling Pronouncement of Appeal Judgment (Supreme Court) 17 November 2011, available at: http:/www.eccc.gov.kh/en/document/court/ order-scheduling-pronouncement-appeal-judgment (last visited 27 November 2011).

171 See, e.g., Guy de Launey, 'Tears and disbelief at Duch verdict', $B B C$ News, 26 July 2010, available at: http:// www.bbc.co.uk/news/world-asia-pacific-10763409 (last visited 20 December 2011).

172 Ibid. See also, e.g., Robin McDowell, 'For most Cambodians, “justice” has little meaning', in Associated Press, 8 August 2010, available at: http:/Www.guardian.co.uk/world/feedarticle/9211885 (last visited 20 December 2011).

173 Author' personal communication with staff members at the TPO, 6 September 2010.

174 See Transcultural Psychosocial Organization, Report on TPO's After-Verdict Intervention with Case 001 Civil Parties, 27 July 2010, pp. 2-3.

175 As of 21 November 2011, 3,866 people were recognized as civil parties in Case 002. Earlier, the Office of the Co-Investigating Judges had rejected 1,846 civil party applications - nearly half of the 3,988 applications in the case. See, ECCC Court Report, Issue 29, Phnom Penh, September 2010, p. 4. On 24 June 2011, the Pre-Trial Chamber granted civil party status to 1,728 Case 002 civil party applicants who were previously rejected as inadmissible. See ECCC Public Affairs, 'Pre-Trial Chamber overturns previous rejections of $98 \%$ of appealing civil party applicants in Case 002', Press Release, 24 June 2011, available at: http:/www.ecc.gov.kh/en/articles/pre-trial-chamber-overturns-previous-rejection-98-appealing-civilparty-applicants-case-002 (last visited 20 December 2011). The Pre-Trial Chamber's decision can be downloaded at: http:/Www.ecc.gov.kh/en/document/court/decision-appeals-against-orders-coinvestigating-judges-admissibility-civil-party-app (last visited 20 December 2011). See also Fédération 


\section{Civil parties' reactions to the verdict}

In the weeks following the verdict, we spoke with seventeen of the twenty-one civil parties whom we had interviewed in late 2009. The purpose was twofold: to inquire whether they felt the verdict was just and whether it had affected their overall experience as a civil party. In this regard, it is helpful to keep in mind that people commonly equate the hierarchical gravity of crimes - especially those involving thousands and tens of thousands of deaths - to the number of years that perpetrators have to serve in prison. But, as profoundly disappointing as a lenient sentence may be to victims, as evidenced below, it does not necessarily mean that the sentence will permanently tarnish their perception of the court and their own experience as a witness or civil party. ${ }^{176}$

Most of the civil parties whom we interviewed after the verdict felt that the sentence was unacceptably low and many hoped that an appellate court would eventually redress what one characterized as ' $50 \%$ justice'. 'All civil parties are unhappy', said Chum Mey. 'Thirty-five years is a lenient sentence. Duch killed a lot of people. He does not deserve such [leniency]'. ${ }^{177}$ Despite considerable disappointment (and some anger) about the sentence, none of the seventeen civil parties whom we interviewed at this point felt that the trial itself was unfair. For Martine Lefeuvre, the verdict brought freedom: 'The verdict has liberated me. It has liberated Ket and [given] him back his dignity. I feel as if I have sprouted wings'. ${ }^{178}$ Van Nath, a survivor of S-21 and a witness (not a civil party), said that he accepted

the Duch verdict because the court did not decide immediately. It spent many years investigating this case, and before handing it down the court described Duch's mistakes. It is fair. And it is like a life sentence for him because Duch is 67 years old already. So I do not think he can serve all these years in prison because his health is not so good as well. ${ }^{179}$

Although dissatisfied with the sentence and other elements of the verdict, Anthonya Tioulong emphasized that the judgment as a whole

is important because it recognizes that Duch is guilty of crimes against humanity and war crimes. It also recognizes the extreme cruelty endured by the victims [at S21] and Duch's individual responsibility. Finally, the judgment acknowledges that his remorse was partial. It is just and [the] truth. ${ }^{180}$

Internationale des Droits de l'Homme-ADHOC-the Center for Justice and Accountability, 'The Extraordinary Chambers in the Courts of Cambodia (ECCC). Opening of the trial in Case 002: expectations of victims from here and abroad', Press Kit, 21 November 2011, p. 5, available at: http://www. fidh.org/IMG/pdf/dpcambodgedec2011_final.pdf (last visited 20 December 2011).

176 See E. Stover, above note 32, pp. 131-136.

177 Interview with Chum Mey, 6 August 2010.

178 Interview with Martine Lefeuvre, 28 July 2010.

179 May Titthara and Sebastian Strangio, 'A mixed reaction to judgment day: the trial ends, but not the debate', in Phnom Penh Post, 27 July 2010, Verdict section, p. 4.

180 Interview with Antonya Tioulong, 31 July 2010. 
Chum Sirath believed that the guilty verdict would help to dispel the belief of many Cambodians, that 'Khmers could never kill Khmers', and that such killings had to have been manipulated by a foreign power. 'The journalists focus on the sentence ... but they have forgotten a crucial point', he said.

It is the first time that a court of law has recognized that crimes committed during the Khmer Rouge regime were committed by Khmers. It is not possible to accuse others anymore; the crimes were committed by Khmers. No one can deny it. This recognition is a big step forward. ${ }^{181}$

Ou Savrith said:

What was important was that Duch was recognized as guilty of the crimes he committed. For victims the number of years he spends in prison can never be enough. Now the verdict is part of history, it is a face, a gesture. A sentence of thirty or forty years or life does not matter. To ask for more is not justice, it is revenge. Justice is not perfect but I do not want to ask for more and spoil what we got. ${ }^{182}$

While disappointed by the lenient sentence that Duch received, many civil parties, including one who was ultimately denied that status, said they still considered their overall experiences as a civil party to be positive. '[Duch] should be in prison until he dies', one respondent said. 'But my experience as [a] civil party has been very good. I got to listen [to the proceedings], and talk about my experience. That made me [feel] better'. 183

After the verdict, Ou Savrith placed some soil and a picture of his brother in an urn and performed a Buddhist ceremony at a pagoda. 'Since the verdict I feel better', he said.

I feel the cycle is finished. I did the most I could for my brother... I feel more serene now ... It is difficult to explain but I feel his soul is still at S-21 so I hope the ceremony can help him be reincarnated.

As for his experience as a civil party, Ou Savrith said he had no regrets. 'I had to do it', he said. 'My brother is no longer anonymous. I am pleased that people know him now and that I had a chance to talk about him... It was difficult but I had to do it. Now I can move on'. ${ }^{184}$

\section{Conclusion}

In this article, we set out to examine how civil parties who testified in the Duch trial viewed their interaction with the ECCC, and what implications their participation in the proceedings and its effects might have for future trials at the

181 Interview with Chum Sirath, 10 August 2010.

182 Interview with Ou Savrith, conducted via telephone, 24 August 2010.

183 Interview, 27 July 2010.

184 Interview with Ou Savrith, above note 182. 
ECCC, the ICC, and other domestic and international war crimes tribunals. So what have we learned?

First, testifying in war crimes trials can potentially be a positive experience for civil parties so long as the process is largely perceived as safe, respectful, and dignified. Among the civil parties whom we interviewed, most mentioned both a positive experience and the fairness of the process. Yet, even when those conditions exist, civil parties can lose faith in a court if they believe that a sentence is too lenient or if they feel that a court has failed to provide reparations commensurate with the gravity of the crimes. While the civil parties whom we interviewed were clearly angered by specific procedures and rulings, especially the lenient sentence given to Duch, they still believed that their participation in the proceedings was meaningful and that justice was rendered.

They characterized their participation in the Duch trial, though at times unnerving and frustrating, as positive. They spoke of their obligation to testify in personal terms, grounded in a duty to confront Duch and to bear witness for those who had perished in S-21. Many said that their appearance in the courtroom helped to restore the dignity of their deceased loved ones and to complete their spiritual journeys as Buddhists.

That said, a considerable number of civil parties seemed deeply disappointed with the Trial Chamber's reduction of Duch's thirty-five-year sentence to nineteen years, the narrow reparations award, and the rejection of twenty-four civil parties. Some expressed frustration that they or others were rejected because of an inability to generate evidence of victimization in a format that the court could recognize, owing to the destruction of documents by the Khmer Rouge regime. The destruction of documents and a lack of documentation generally are not phenomena unique to the Khmer Rouge context; rather, this is a problem that frequently arises with mass atrocities. ${ }^{185}$ The inability of many victims to obtain the kind of documentary evidence that tribunals require suggests that it is critical for courts to modify their standards in some cases, especially if reparations are moral and collective rather than individual financial awards. Alternatively, if the easing of such requirements threatens the defendant's right to a fair trial, it is imperative for courts, lawyers, and NGOs to explain carefully and clearly to applicants, the media, and the general public what rejection as a civil party means: specifically, that the required standards of evidence could not be met, usually through no fault of the applicant, and that such applicants, and perhaps many others, have often been victimized. It may also be critical to develop avenues other than the court proper for victims' status to be recognized and for victims to tell their stories. The potential for collective reparations becomes an essential counterpart to this ability to bear witness. For example, reparations in the form of a day of remembrance can become

185 The ICC has grappled with this issue. For general information about how victims can apply to participate in ICC proceedings, see Office of the Public Counsel for Victims, International Criminal Court, Representing Victims Before the International Criminal Court: A Manual for Legal Representatives, Ipskamp Drukkers B.V, Enschede, 2010. 
an alternative expression of support for victims and a condemnation of the accused that may substitute for a chance to speak in court.

There are signs that the ECCC has recognized some of the structural problems that have plagued victim participation in Case 001. In early 2010, the Court modified three major components of its Rules: the criteria for civil party admissibility, the vetting process, and the structure for legal representation. ${ }^{186}$ The admissibility criteria are now more specific, stating that civil party applicants should be clearly identified and able to demonstrate that their injuries are directly linked to at least one of the crimes alleged against the accused. ${ }^{187}$ This clarification reduces interpretation on admissibility of civil parties and provides advance parameters for applicants to follow, potentially diminishing rejections. In addition, the Office of the Co-Investigating Judges is now responsible for vetting all civil parties prior to trial. Finally, in an effort to limit the number of civil party lawyers in the courtroom, the ECCC has decided that two Co-lead Counsel (one international and one Cambodian) will represent all of the civil parties during the actual proceedings. The Co-lead Counsel will be hired and paid for by the ECCC, and assisted by specialized civil party lawyers who will represent various sub-groups and interests and serve as the link between their clients and the Co-lead Counsel. ${ }^{188}$

While rectifying these structural problems could go a long way toward improving civil party participation at the ECCC, much more needs to be done to educate witnesses, civil parties, and, indeed, the general population about the Court's limitations, as well as its rules and procedures (most of which are quite alien to Cambodians). Of utmost importance, especially during the pre-trial and trial phases, is the need to keep civil parties and witnesses informed about developments in the proceedings. As the criminologist Jo-Anne Weemers writes:

Information and notification... send a message to victims that they are not forgotten and they recognize their interest in the case... Victims who are informed of their rights and notified of developments in their case tend to be more satisfied with the justice system and feel that they are treated fairly. ${ }^{189}$

Conversely, a lack of information and transparency can send the opposite message to victims and witnesses. This has already happened in Case 003 at the ECCC. On 24 October 2011, Rowan Downing and Katinka Lahuis, two international judges in a pre-trial chamber that rules on disputes while a case is still under investigation, issued a minority decision listing a string of questionable actions by Co-Investigating Judges Siegfried Blunt and You Bunleng. Blunt and You jointly headed the Office of the Co-Investigating Judges prior to Blunt's resignation on 9 October. Downing and Lahuis said that Blunt and You had backdated documents, inexplicably refused to recognize civil party lawyers, prevented civil

186 ECCC, Internal Rules (revision 5), above note 55, Rule 12 ter, Rule 23 bis, Rule 23 ter (1).

187 Ibid., Rule 23 bis (1).

188 Ibid., Rule 12 ter, Rule 23 bis (2), Rule 23 bis (3).

189 This finding has been confirmed in numerous studies. For a general review of these studies, see Jo-Anne Wemmers, 'Victims' rights and the International Criminal Court: perceptions within the court regarding the victims' right to participate', in Leiden Journal of International Law, Vol. 23, 2010, p. 641. 
party lawyers from accessing case files despite repeated requests, and, in doing so, had 'deprived some civil party applicants... of the fundamental right to legal representation'. 190

Our second finding is that the civil parties' generally positive attitudes about the Duch trial process may not be echoed in future ECCC or ICC cases. Why is this? To begin with, memories of wartime atrocities, like all memories, are both personal and local; they consist of specific places and actors and moments in time embedded in the psyche of individual victims and witnesses. The Duch trial complemented these elements. It featured: (1) a single defendant who, early in the proceedings, expressed remorse for his crimes; (2) a 'crime scene' confined to a specific location - namely, the grounds of the S-21 detention centre (and the related facility known as S-24); and (3) the participation of ninety civil parties, twenty-two of whom testified largely because they viewed Duch as the individual most directly responsible for the death of their loved ones. Their desire - denied for nearly thirty years - to confront Duch and discover the truth drew them towards and into the judicial process. Once inside the system, they were able, for the most part, to fulfil their personal and spiritual obligations to obtain some modicum of justice for their loved ones and themselves.

In comparison, Case 002 involves (1) three senior Khmer Rouge leaders who have refused to talk; (2) a 'crime scene' that covers diverse locations throughout Cambodia; and (3) a group of nearly 4,000 civil parties who will be confronting aging defendants with no (or, at best, very little) knowledge of the local circumstances surrounding the deaths of the civil parties' loved ones. As a result, what the civil parties take away from their participation in Case 002 may be more formulaic and less individualized, and therefore less transformative. To test this hypothesis, it will be important to conduct a similar interview study of civil parties once the verdict has been rendered in Case 002 .

Our findings in the Duch trial may have implications for 'victim participation' at the International Criminal Court and the level of satisfaction that victim participants have as a result of their association with the court. The ICC Strategy in Relation to Victims, a court-wide document that addresses victim-related issues, notes that:

by providing victims with an opportunity...to be part of the justice process and by ensuring that consideration is given to their suffering, it is hoped that they will have confidence in the justice process and view it as relevant to their day to day existence rather than as remote, technical and irrelevant. ${ }^{191}$

190 See ECCC, Case No. 003/07-09-2009-ECCC/OCIJ (PEC 02), Public (Redacted Version): Considerations of the Pre-Trial Chamber Regarding the Appeal Against Order on the Admissibility of Civil Party Applicant Robert Hamill, Opinion of Judges Lahuis and Downing, para. 7, available at: http//www.ecc.gov.kh/en/ document/court/considerations-pre-trial-chamber-regarding-appeal-against-order-admissibility-civil-p (last visited 2 December 2011.

191 International Criminal Court, Report of the Court on the Strategy in Relation to Victims (ICC Strategy in Relation to Victims'), ICC-ASP/8/45, 10 November 2009, para. 46, emphasis added. 
Our findings suggest that ICC victim participants may not have the same 'transformative experience' as the civil parties in the Duch trial for several reasons. First, the vast majority of ICC 'victim participants' will never set foot in the courtroom in The Hague and thus will only be able to experience the trial vicariously through their legal representatives or the media. Second, many victims who wish to participate in ICC proceedings have found the application process 'slow' and 'remote'. ${ }^{192}$ Redress, a victim support organization that has studied the victim participation process at the ICC, reports that many victims view the court as 'out of touch and overly bureaucratic with is numerous lengthy forms and requirements. These forms all require significant amounts of time to complete, in circumstances where victims are eking [out] a living' ${ }^{193}$ Finally, since the ICC is primarily concerned with crimes committed by high-ranking accused, victim participants are most likely to appear in cases involving government leaders, such as Sudan's president Omar Al-Bashir or Libya's former leader Muammar al-Gaddafi, who were physically removed from the actual crime scenes. Many victims especially those who survived massacres or years of torture in captivity - may find these proceedings too formulaic and failing to produce a 'sense of personal justice' that comes from actually confronting the person most directly responsible for your (or a loved one's) suffering. Of course, such observations are purely hypothetical; interview surveys will need to be conducted with ICC victim participants to probe the meaning that they have derived from the experience of testifying or participation.

Our third finding is that civil party lawyers and local NGO activists, through their outreach and support services to victims, can provide vital assistance to international criminal courts. Indeed, we found that Cambodian NGO activists and civil party lawyers, especially those with an in-country presence, filled a huge void in the Duch trial by providing legal, emotional, and psychosocial support to victims. With limited funding, these activists and lawyers mobilized networks throughout Cambodia to encourage civil party participation at the Court, and did their best to ensure that those who entered the system understood its laws and procedures. ${ }^{194}$ Our interviews suggest that the attention that the TPO and other NGOs and lawyers paid to the informational, psychological, and cultural needs of civil parties positively influenced their views of the tribunal.

Though the first trial has ended, these NGOs and lawyers continue in their mission: they are maintaining contact with many of the civil parties who were rejected and/or dissatisfied with the outcome of the Duch trial to provide social and

192 Victims' Rights Working Group, 'The impact of the Rome Statute on victims and affected communities', 22 March 2010, p. 15, available at: http:/Www.vrwg.org/VRWG_DOC/2010_Apr_VRWG_ Impact_of_ICC_on_victims.pdf (last visited 4 September 2011).

193 See Redress, 'Victims' central role in fulfilling the ICC's mandate', November 2009, p. 6, available at: http:/www.redress.org/downloads/publications/ASP\%208\%20Paper\%20FINAL\%20Nov\%202009.pdf (last visited 4 September 2011).

194 In our view, staff in a few of these organizations also did a disservice to civil parties by encouraging them to call for individual reparations when it was clear that the ECCC had already decided that it would only rule on 'collective and moral reparations'. Our interviews suggest that such encouragement created unrealistic expectations on the part of some civil parties. 
psychological support, and to ensure that any lingering or appeals-related questions are answered. Their involvement may be just as crucial in Case 002, which has nearly 4,000 accepted civil parties, and may ultimately shape the Court's long-term legacy. It is in the best interests of international tribunals to engage local NGOs in outreach efforts to victims, and to maintain clear and consistent communication with them before, during, and after the trial process. It may even behove courts to formalize their relationship with such NGOs and facilitate the creation of an official or unofficial network of local organizations to meet the needs of victim participants.

Fourth, if the ECCC and other international criminal tribunals grant victims the right to participate in proceedings, they must develop clear, comprehensive, and consistent procedures early on in the life of the court to define, encourage, and manage that participation without impeding the rights of the accused. During the Duch trial, civil party participation often appeared as if it was a work-in-progress rather than a process guided by well-honed rules and procedures. At various points in the proceedings, the ECCC would grapple with several significant issues relating to implementing this novel mechanism, including how best to define the exact purpose of civil party participation and the role that civil party lawyers would play in the proceedings. Moreover, outside the courtroom, it was not the ECCC but Cambodian human rights workers and civil party lawyers who guided and supported civil parties through the various phases of the trial.

Providing victims with the right to participate implies an obligation not to create false hopes or place victims in situations where their physical or psychological safety may be at risk. This requires defining the exact purpose of victim participation before the first case commences and developing clear procedures for victim participation. Of particular importance is the need to make it clear to victim participants from the outset that their application may not be accepted, or, if accepted, that they may not be selected to testify. Finally, courts should not embrace victim participation unless they are able and willing to provide adequate funding and manpower to process applications in a timely manner and maintain consistent communication with applicants throughout the process.

Finally, as the world community increasingly turns to international criminal justice as a response to mass violence, we must re-examine how we think about and interact with victims who participate in court proceedings. We should consider whether or not victim participation beyond that of 'the victim as witness' is always in the best interests of victims or justice. Our interviews with civil parties and key informants suggest that participation in the Duch trial was meaningful for the victims and helped to inform and humanize the proceedings. And no trial observer - at least that we are aware of - has put forward a credible case suggesting that civil party participation impinged on the defendant's right to a fair trial, which has long been considered one of the greatest risks of such participation. However, what distinguished this group of victims was the fact that they were able to testify in court. In Case 002, with 3,866 victims designated as civil parties, it is likely that only a very small percentage will ever appear in the courtroom. What then will participation mean for the vast majority who do not testify or even attend a hearing? Will they still derive some meaning from the process? This remains an empirical 
question worth clarifying. Moreover, it is not a forgone conclusion that civil party participation will proceed smoothly in Case 002. For example, Patricia Wald, a former judge with the ICTY, has warned that national leaders who are brought to trial for serious international crimes may use the trial chamber to threaten witnesses and foment nationalist fervour. ${ }^{195}$ The ECCC's second trial, which features four defendants, faces a heightened potential for the politicization of the proceedings and the possibility that defendants will attempt to dominate the trial at the expense of victims.

All of this suggests that it is unwise to valorise expanded participatory rights for victims without being mindful of the possible pitfalls. Some of the most threatening are re-victimizing civil parties, recognizing some victims at the exclusion of others, creating multiple and potentially conflicting prosecutorial strategies (with some strategies endorsed only by the prosecutor and others by the civil parties), adding more bureaucracy, impeding the defendant's right to a fair trial, failing to provide civil parties with access to hearings and logistical support, and increasing both the cost and length of trials. It also suggests that international courts and NGOs might want to explore mechanisms for victims to tell their story in a setting other than the trial and develop alternatives for involving participants.

Victim participation is still in its infancy, and there is a critical need to develop common standards, at both a practical and a legal/normative level, to guide international criminal tribunals and to maximize the potential for justice. Ultimately, our research suggests that meeting victims' needs and ensuring meaningful and productive participation requires a clear and orchestrated effort something that courts may not be able to accomplish on their own.

195 Patricia M. Wald, 'Tyrants on trial: keeping order in the courtroom', Open Society Institute, September 2009, available at: http//www.soros.org/initiatives/justice/articles_publications/publications/tyrants_ 20090911/tyrants_20090911.pdf (last visited 20 December 2011). 